\title{
Rare and Emerging Viral Infections in the Transplant Population
}

\author{
Susanna K. Tan, Jesse J. Waggoner, and Stan Deresinski
}

\section{List of Abbreviations}

$\begin{array}{ll}\text { AIDS } & \text { Acquired immune deficiency syndrome } \\ \text { APMV-1 } & \text { Avian paramyxovirus 1 } \\ \text { ATL } & \text { Adult T-cell leukemia } \\ \text { CDC } & \text { US Centers for Disease Control and Prevention } \\ \text { cDNA } & \text { Complementary DNA } \\ \text { CHIKV } & \text { Chikungunya virus } \\ \text { CMV } & \text { Cytomegalovirus } \\ \text { CSF } & \text { Cerebrospinal fluid } \\ \text { DENV } & \text { Dengue virus } \\ \text { DF } & \text { Dengue fever } \\ \text { DFA } & \text { Direct fluorescent antibody } \\ \text { DHF } & \text { Dengue hemorrhagic fever } \\ \text { DNA } & \text { Deoxyribonucleic acid } \\ \text { DSS } & \text { Dengue shock syndrome } \\ \text { FLAIR } & \text { Fluid-attenuated inversion recovery } \\ \text { GVHD } & \text { Graft-versus-host disease } \\ \text { HAM } & \text { HTLV-associated myelopathy } \\ \text { HBoV } & \text { Human bocavirus } \\ \text { HCV } & \text { Hepatitis C virus } \\ \text { HEV } & \text { Hepatitis E virus } \\ \text { HFRS } & \text { Hemorrhagic fever with renal syndrome } \\ \text { HHV-8 } & \text { Human herpes virus 8 } \\ \text { HIV } & \text { Human immunodeficiency virus } \\ \text { hMPV } & \text { Human metapneumovirus } \\ \text { HPS } & \text { Hantavirus pulmonary syndrome } \\ \text { HSCT } & \text { Hematopoietic stem cell transplant } \\ \text { HTLV-1 } & \text { Human T-cell leukemia virus 1 }\end{array}$

S. K. Tan $(\bowtie) \cdot$ S. Deresinski

Stanford University School of Medicine, Department of Medicine, Division of Infectious Diseases and Geographic Medicine,

Stanford, CA, USA

e-mail: susietan@stanford.edu; stan@polishmd.com

\section{J. J. Waggoner}

Emory University School of Medicine, Department of Medicine, Division of Infectious Diseases, Atlanta, GA, USA

e-mail: jesse.j.waggoner@emory.edu

$\begin{array}{ll}\text { HYSV } & \text { Huaiyangshan virus } \\ \text { Ig } & \text { Immunoglobulin } \\ \text { IHC } & \text { Immunohistochemistry } \\ \text { IV } & \text { Intravenous } \\ \text { IVIG } & \text { Intravenous immunoglobulin } \\ \text { JEV } & \text { Japanese encephalitis virus } \\ \text { LCMV } & \text { Lymphocytic choriomeningitis virus } \\ \text { MDMA } & \text { 3,4-methylenedioxymethamphetamine (ecstasy) } \\ \text { MMLV } & \text { Moloney murine leukemia virus } \\ \text { MMR } & \text { Measles, mumps, and rubella vaccine } \\ \text { NP } & \text { Nasopharyngeal } \\ \text { OPO } & \text { Organ procurement organization } \\ \text { OPTN } & \text { US Organ Procurement and Transplantation Network } \\ \text { PARV4 } & \text { Parvovirus 4 } \\ \text { PBMC } & \text { Peripheral blood mononuclear cell } \\ \text { PCMV } & \text { Porcine cytomegalovirus } \\ \text { PCR } & \text { Polymerase chain reaction } \\ \text { PEP } & \text { Postexposure prophylaxis } \\ \text { PERV } & \text { Porcine endogenous retrovirus } \\ \text { PLHV } & \text { Porcine lymphotropic herpesvirus } \\ \text { RDA } & \text { Representation difference analysis } \\ \text { RNA } & \text { Ribonucleic acid } \\ \text { RSV } & \text { Respiratory syncytial virus } \\ \text { RT-PCR } & \text { Reverse transcription polymerase chain reaction } \\ \text { RVFV } & \text { Rift Valley fever virus } \\ \text { SARS } & \text { Severe adult respiratory syndrome } \\ \text { SFTSV } & \text { Severe fever with thrombocytopenia syndrome } \\ & \text { virus } \\ \text { SISPA } & \text { Sequence-independent single-primer amplification } \\ \text { SME } & \text { Subacute measles encephalitis } \\ \text { SOT } & \text { Solid organ transplant } \\ \text { TBEV } & \text { Tick-borne encephalitis virus } \\ \text { TNF } & \text { Tumor necrosis factor } \\ \text { TTV } & \text { Torque teno virus } \\ \text { USUV } & \text { Usutu virus } \\ \text { WNV } & \text { West Nile virus } \\ \text { XMRV } & \text { Xenotropic murine leukemia virus-related virus } \\ \text { YFV } & \text { Yellow fever virus } \\ \text { ZIKV } & \text { Zika virus } \\ & \end{array}$




\section{Introduction}

An emerging infectious disease, as defined by the Institute of Medicine and adopted by the $\mathrm{CDC}$, is an infectious disease whose incidence in the human population has increased in the preceding two decades or threatens to increase in the near future $[1,2]$. Viral diseases account for a large proportion of such infections, and the emerging viruses are typically divided into two groups: (1) newly identified viruses and (2) previously recognized viruses with an apparent increase in disease incidence [3, 4]. When applied to the transplant population, this second category can include agents with no recognized pathogenicity in the immunocompetent patient and those that result in atypical, more frequent, or more severe disease presentations in the immunocompromised host [5].

In this chapter, we will begin by discussing viral diagnostics and the rapidly evolving field of viral discovery, which has increased the speed of virus identification but has brought along new challenges for clinicians and researchers. Our focus then shifts to discussing specific emerging and re- emerging viral pathogens in the transplant community (see Tables 45.1 and 45.2). A number of emerging viral pathogens in the transplant population are discussed in detail in other chapters throughout this text (human herpes virus 7 , human metapneumovirus, hepatitis E virus (HEV), novel polyomaviruses, and non-SARS coronaviruses) and will not be covered further here. Recent reviews in the literature have also discussed the topics of emerging viral infections in transplant recipients generally [4-10], as well as in solid organ transplant (SOT) [11] and hematopoietic stem cell transplant (HSCT) recipients specifically [12].

Following the discussion of emerging viral pathogens identified in the transplant community, we will briefly discuss global emerging viral pathogens, including flaviviruses, alphaviruses, bunyaviruses, and filoviruses. Given the nature of many of these pathogens, including their endemic ranges or relatively recent identification, few, if any, reports exist on their presentation in transplant recipients. Finally, we discuss the special situation of xenotransplantation and the reporting of suspected emerging viral diseases.

Table 45.1 Rare and emerging viral infections in the transplant population: case series or multiple cases reported [10]

\begin{tabular}{|c|c|c|c|c|}
\hline Species & Virus family & Transplant & Clinical manifestations & Comments \\
\hline HTLV-1 & Retroviridae & $\begin{array}{l}\text { SOT and HSCT; } \\
\text { donor-derived } \\
\text { infections reported }\end{array}$ & $\begin{array}{l}\text { Adult T-cell leukemia and HTLV-1 } \\
\text { associated myelopathy }\end{array}$ & $\begin{array}{l}\text { Associated with lower survival after HSCT from } \\
\text { HTLV-1+ donor }\end{array}$ \\
\hline Rabies & Rhabdoviridae & $\begin{array}{l}\text { SOT, ileac artery } \\
\text { graft, cornea } \\
\text { transplants; all cases } \\
\text { donor-derived }\end{array}$ & $\begin{array}{l}\text { Fatal encephalitis; cornea } \\
\text { transplants present with pain } \\
\text { in eye with graft }\end{array}$ & $\begin{array}{l}\text { Survivors reported: cornea transplant with } \\
\text { immediate PEP; liver transplant } 20 \text { years after } \\
\text { vaccination; two exposed cornea transplants, } \\
\text { grafts negative by RT-PCR }\end{array}$ \\
\hline $\begin{array}{l}\text { LCMV and } \\
\text { a novel } \\
\text { arenavirus }\end{array}$ & Arenaviridae & $\begin{array}{l}\text { SOT; all reported } \\
\text { cases donor-derived }\end{array}$ & $\begin{array}{l}\text { Fever, abdominal pain, nausea, } \\
\text { vomiting, diarrhea, altered mental } \\
\text { status; often peri-incisional rash } \\
\text { and tenderness }\end{array}$ & $\begin{array}{l}14 \text { of } 17 \text { patients died; ribavirin employed but } \\
\text { effect unclear; three cornea transplants } \\
\text { unaffected; evidence of LCMV in donor rarely } \\
\text { found }\end{array}$ \\
\hline Measles & Paramyxoviridae & SOT and HSCT & $\begin{array}{l}\text { Occasional clinical measles; } \\
\text { SME (afebrile, altered mental } \\
\text { status, intractable seizures); } \\
\text { interstitial pneumonia }\end{array}$ & $\begin{array}{l}\text { SME fatal in } 4 / 6 \text { transplant patients; case series } \\
\text { suggest severe measles represents minority of } \\
\text { cases in transplant patients }\end{array}$ \\
\hline Mumps & Paramyxoviridae & SOT and HSCT & $\begin{array}{l}\text { Parotitis, orchitis, vestibular } \\
\text { neuronitis, and renal allograft } \\
\text { involvement (SOT); fatal } \\
\text { encephalitis (HSCT) }\end{array}$ & $\begin{array}{l}\text { Three cases in SOT, all renal transplant patients } \\
\text { and all survived; single case in HSCT }\end{array}$ \\
\hline Dengue & Flaviviridae & SOT and HSCT & $\begin{array}{l}\text { Dengue fever, severe dengue } \\
\text { including hemorrhagic fever and } \\
\text { shock; single case of colitis } \\
\text { reported }\end{array}$ & $\begin{array}{l}\text { Dengue shock associated with high mortality; } \\
\text { rates of severe dengue differ in case series }\end{array}$ \\
\hline Orf & Poxviridae & $\begin{array}{l}\text { SOT; infected from } \\
\text { contact with infected } \\
\text { sheep }\end{array}$ & $\begin{array}{l}\text { Giant and recurrent skin } \\
\text { lesions on hands and forearms }\end{array}$ & $\begin{array}{l}\text { Often misdiagnosed and treated with excision or } \\
\text { amputation; case reports document responses to } \\
\text { cryotherapy, cidofovir cream, or imiquimod }\end{array}$ \\
\hline Bocavirus & Parvoviridae & SOT and HSCT & $\begin{array}{l}\text { Associated with LRTI in young } \\
\text { children; disseminated infection in } \\
\text { transplant patients documented }\end{array}$ & $\begin{array}{l}\text { Clinical significance of infection or reactivation } \\
\text { in the immunocompromised patient remains } \\
\text { unclear; no treatment available }\end{array}$ \\
\hline Parvovirus 4 & Parvoviridae & SOT & $\begin{array}{l}\text { Associated with "viral syndrome" } \\
\text { or early HIV; detected in renal and } \\
\text { lung transplant recipients }\end{array}$ & $\begin{array}{l}\text { Clinical significance in the immunocompromised } \\
\text { patient remains unclear, thus far not associated } \\
\text { with disease }\end{array}$ \\
\hline
\end{tabular}

Reprinted from Waggoner et al. [10], by permission of Oxford University Press

$H S C T$ hematopoietic stem cell transplant, $H T L V-1$ human T-cell leukemia virus 1, IVDU intravenous drug users, $L C M V$ lymphocytic choriomeningitis virus, LRTI lower respiratory tract infection, PEP postexposure prophylaxis, SME subacute measles encephalitis, SOT solid organ transplant 
Table 45.2 Rare and emerging infections in the transplant population: single cases reported [10]

\begin{tabular}{|c|c|c|c|c|}
\hline Species & Virus family & Transplant & Clinical manifestations & Comments \\
\hline APMV-1 & Paramyxoviridae & HSCT & $\begin{array}{l}\text { Fatal pneumonia; no other pathogens } \\
\text { identified }\end{array}$ & $\begin{array}{l}\text { Known pathogen in birds; tested in virotherapy for } \\
\text { certain malignancies }\end{array}$ \\
\hline Chikungunya & Togaviridae & SOT & $\begin{array}{l}\text { Fever, headache, abdominal pain; no } \\
\text { arthritis or arthralgia; recovered fully }\end{array}$ & $\begin{array}{l}\text { Identified in four corneal grafts during Reunion } \\
\text { outbreak, no transplant cases reported }\end{array}$ \\
\hline Monkeypox & Poxviridae & HSCT & $\begin{array}{l}\text { Fever and headache followed by } \\
\text { characteristic rash (similar to smallpox) }\end{array}$ & $\begin{array}{l}\text { Clinical course not reported as severe, patient } \\
\text { recovered, though full details not reported }\end{array}$ \\
\hline Usutu virus & Flaviviridae & SOT & $\begin{array}{l}\text { Fever and headache; recovered but required } \\
\text { prolonged rehabilitation }\end{array}$ & $\begin{array}{l}\text { Viremic prior to developing liver failure and } \\
\text { receiving liver transplant }\end{array}$ \\
\hline Hantavirus & Bunyaviridae & SOT & $\begin{array}{l}\text { Fever, headache, arthralgia, oliguric renal } \\
\text { failure }\end{array}$ & $\begin{array}{l}\text { Dobrava-Belgrade virus isolated (mild HFRS), no } \\
\text { cases of HPS reported }\end{array}$ \\
\hline
\end{tabular}

Reprinted from Waggoner et al. [10], by permission of Oxford University Press

$A P M V$-1 avian paramyxovirus $1, H F R S$ hemorrhagic fever with renal syndrome, HPS hantavirus pulmonary syndrome, HSCT hematopoietic stem cell transplant, SOT solid organ transplant

\section{Methods}

The body of literature referenced in this chapter is no doubt fraught with bias as it is largely based on case reports and small case series. Our understanding of most of these emerging viral infections, including their incidence, clinical manifestations, diagnosis, and management, in the immunocompromised host is limited, and larger, prospective studies in endemic areas are necessary. With the increasing number of transplants, both SOT and HSCT, performed globally, any description of emerging viral infections in this population will require frequent monitoring and updating. For the purposes of this chapter, we performed searches of the medical literature in PubMed, limited to studies reported in English. Searches were performed through May of 2016, using the name of the virus family, genus, or species of interest matched with the search terms "transplant," "transplant*," and "immunocompromised." We also performed general searches for emerging viruses and transplant recipients to identify case reports of novel or rare pathogens causing disease in transplant recipients. Finally, we included pertinent references from the publications identified during our search. With rare exceptions, we excluded reports involving only patients with HIV or AIDS.

\section{Viral Discovery and Disease Association}

Clinical virology laboratories affiliated with transplant centers typically employ a range of techniques for the diagnosis of viral infections from patient samples as well as for the quantitation and resistance testing of certain viruses. These techniques include, but are not limited to, viral culture, serology, antigen detection, direct fluorescent antibody staining (DFA), polymerase chain reaction (PCR) and reversetranscription PCR (RT-PCR), and sequencing of certain pathogens (particularly HIV). While viral diagnostics are discussed in detail elsewhere in the text, we will briefly dis- cuss these tests in the context of emerging viral infections followed by a discussion of newer technologies employed in viral discovery.

Viral culture provides a semi-unbiased technique for virus identification from patient samples, though this is a laborintensive process and often requires days to weeks to detect viral growth. Many viral pathogens do not grow well, or do not grow at all, in cell culture, and viral detection is limited by the range of cells on which a given virus will grow and the number of cell lines a given lab can maintain. Even when cytopathic effect develops in a cell monolayer, the virus has to be identified by other means (often DFA or PCR). The majority of the viruses discussed in this chapter are diagnosed by other means, though agents such as lymphocytic choriomeningitis virus (LCMV) and dengue can be grown in culture as well $[13,14]$.

The other testing modalities routinely offered in a clinical virology lab, or even specialized tests performed at state and national reference laboratories, utilize conserved sequences (in the case of PCR or RT-PCR) or specific antigens or antibodies to detect the causative virus in patient samples. Hence, pathogen detection is limited by the knowledge and judgment of the ordering clinician or the available tests. The increasing use of multiplex testing for clinical syndromes, particularly for respiratory tract infections, will allow for a less biased approach to viral diagnosis but still faces limitations in identifying rare or emerging pathogens [15]. It should be noted that in very rare situations, as in the case of Usutu virus (USUV) discussed below, an unusual or novel pathogen may be detected by testing for known pathogens. In this case, a woman presented with USUV viremia, which gave a low-positive result by WNV PCR and was eventually identified by sequencing [16].

Viral discovery has typically relied on the replication of a new virus in cell culture. Despite the aforementioned limitations of viral culture, this technique remains useful, as indicated by the identification of two novel bunyaviruses, Huaiyangshan virus (HYSV, also known as severe fever with 
thrombocytopenia syndrome virus, SFTSV) in China and Heartland virus [17, 18] A number of more rapid molecular methods are now being employed in viral discovery; however, these are typically categorized as sequence-dependent (such as the pan-viral microarray or PCR based on conserved sequences) or sequence-independent techniques [19]. The pan-viral microarray (Virochip) is an array spotted with oligonucleotide sequences representing all known viral pathogens. Novel viruses can also be identified if there is sufficient similarity between sequences in the new virus and those included on the array. Amplicons can be then be recovered from the array, cloned, and sequenced [20]. This technology has been used in the identification of the SARS coronavirus, $\mathrm{XMRV}$, and was also tested as a means to rapidly identify the 2009 pandemic influenza strain (H1N1) [19, 21]. PCR based on conserved sequences is possible but generally has limited applicability in viral diagnostics, as viruses do not contain highly conserved sequences analogous to the 16 s ribosomal sequences utilized in bacterial identification [22]. One example of this is the performance of PCR using primer sets that amplify members of a virus family followed by sequencing, as reported in the identification of USUV from patient samples using a pan-flavivirus RT-PCR [16, 23].

The sequence-independent amplification and sequencing of nucleic acids in biological fluids or environmental samples has been termed viral metagenomics [19, 24]. Sequenceindependent approaches include subtractive hybridization or representation difference analysis (RDA), sequenceindependent single-primer amplification (SISPA), rolling circle amplification, and next-generation sequencing. Subtractive hybridization or representational difference analysis (RDA) uses infected and uninfected samples from an individual patient. Viral nucleic acid is selectively concentrated by repeated rounds of hybridization and purification of the unhybridized, single-stranded nucleic acid molecules, which are then subcloned and sequenced. These techniques have been used in the identification of human herpes virus 8 (HHV-8) and the torque teno viruses (TTV), but they require large amounts of starting material as well as relatively high virus levels [19, 22, 25]. SISPA circumvents the need for large amounts of viral genomic material. This technique, introduced in 1991, and its derivations involve the attachment of a linker/ primer to blunt-ended nucleic acid and the subsequent amplification of all nucleic acid present, followed by cDNA library creation and sequencing [26]. SISPA was utilized in the identification of HEV, Norwalk virus, and Parvovirus 4 [22, 27]. Rolling circle amplification involves the use of the PhiX29 polymerase primed with random primers to amplify circular viral genomes or cloned fragments. It was used in the identification of human bocavirus (HBoV) among others [19, 28].

Viral metagenomics has been aided in the last few years by the development of a number of new sequencing platforms. Termed "next-generation sequencing" or "deep- sequencing," such technologies allow for the rapid and parallel generation of one million to over one billion sequences per run. Most of the current technologies rely on the non-specific amplification of DNA or RNA molecules followed by sequencing by synthesis using different technologies to detect base incorporation [22, 24, 29, 30]. Recently, single-molecule sequencing has become available, and this technology continues to develop, resulting in a greater number of reads (i.e., deeper sequencing) and longer read lengths [30]. These technologies are able to detect viral copy numbers near the limit of detection for specific quantitative PCR assays and have been shown to be more sensitive than microarray analysis ( 2 per $10^{6}$ versus 1 per $10^{5}$ sequences in one study) [31, 32]. Next-generation sequencing has been utilized to identify novel viruses in patient samples (see arenaviruses below) and determine the cause of fevers of unknown origin [32-35]. The potential utility of direct sequencing in the outbreak setting has also been shown following the 2009 influenza pandemic [21].

Deep sequencing, to the extent that it is sensitive and sequence-independent, has a great ability to detect both known and previously unknown (divergent) viruses as well as provide phylogenetic information. What it cannot do, however, is demonstrate causation. For many of these viruses, classical Koch's postulates cannot be applied, and as recently demonstrated in the cases of TTV, GB virus $C$, and human bocavirus ( $\mathrm{HBoV})$, establishing a causative role for many of these agents can be difficult [22, 25, 36]. Mokili and colleagues have instead proposed an approach they call "Metagenomic Koch's Postulates," but whether they are sufficient remains a matter for discussion [22].

At this time (and for the near future), next-generation sequencing remains a tool for research purposes rather than clinical diagnostics. Sequencing reactions take a good deal of time to set up and perform, with run times between $12 \mathrm{~h}$ and 14 days [29]. These runs also generate massive amounts of data that must be filtered to remove human and lowcomplexity sequence prior to analysis using various alignment programs designed to handle the large numbers of short reads [29, 32]. Finally, results must be interpreted carefully, as contaminants from the laboratory and even from commercial reagents, such as Moloney murine leukemia virus (MMLV, from polymerase preparations), are often identified $[21,32]$. Confirming the presence of a virus identified with small numbers of sequences can also be difficult. In the study of metagenomics following the 2009 influenza pandemic, one patient from British Columbia was found to have two sequences matching an Ebola Sudan isolate, and during the evaluation of children in Nicaragua with fevers of unknown origin, a child had sequence similar to African swine fever virus [21, 32]. Run-time and data management and analysis will need to be streamlined before such technology will be applicable for relatively routine use in a clinical laboratory. 


\section{Emerging and Re-emerging Pathogens}

\section{Human T-Cell Leukemia Virus Type 1}

Human T-cell leukemia virus type 1 (HTLV-1) infection is endemic in Japan, West Africa, South America, the Middle East, and the Caribbean with seroprevalence ranging approximately from $3 \%$ to $30 \%$, while in western countries $<1 \%$ are infected [37]. Most of the millions who are affected acquired their infections vertically via breast milk, but this retrovirus may also be transmitted by blood transfusion, sharing of needles, and organ transplantation. A number of complications are associated with chronic HTLV-1 infection, most frequently adult T-cell leukemia (ATL) and HTLV-associated myelopathy (HAM), which occur in 5\% or fewer of those infected. Immunosuppression administered to transplant recipients who are HTLV-1 carriers may trigger progression to these known complications of the infection (for a brief summary, see Table 45.1) [38-40]. Numerous reports document the devastating clinical impact of ATL and HAM from HTLV-1 infection in solid organ transplant recipients [38, $41,42]$. The majority of these cases are from Spain and Japan, though additional reports in the United States have surfaced in recent years involving donors and recipients with expected epidemiologic risk factors (i.e., residence in endemic regions) [43, 44].

Complications from HTLV-1 can be a result of reactivation disease in HTLV-1/2 seropositive recipients, de novo primary infection, and donor-derived infection in organ transplant recipients. In a nationwide survey in Japan, Yoshizumi et al. identified 82 living donor liver transplant recipients who were HTLV-1 positive prior to transplantation. ATL developed in 5 of these $26(15.4 \%)$ after intervals of 181-1315 days after transplantation. All five died, four due to ATL and one due to rejection after reduction in immunosuppressive therapy. In a compelling case series of donorderived HTLV-1 infection, liver and two kidney recipients from HTLV-1 seropositive donor were acutely infected with HTLV-1 with rapid dissemination early in the posttransplant period. HTLV-1 provirus was detected by PCR on days $16-23$ and increased by $2-3 \operatorname{logs}$ by day $38-45$, after which steady state was reached. HTLV-1 antibodies were first detected between 16 and 39 days following transplantation. Alignment of the HTLV-1 5' LTR of the donor and the three recipients showed $100 \%$ sequence identity consistent with a common viral source of infection. Though no cases of early onset or rapid progression of HAM were observed in this series, in another case series, all three HLTV-1-negative recipients of organs from a single HTLV-1-positive donor (two kidney transplants and a liver transplant) developed antibodies to the retrovirus and developed HAM within the 2 years of transplantation. HTLV-1 isolates from these three recipients were homologous to the donor isolate by DNA sequencing $[45,46]$. Two case reports also document the occurrence of HAM in a heart transplant recipient and an HSCT recipient who both acquired HTLV-1 through blood transfusions $[39,47]$.

Despite these case examples, clinical disease due to HTLV-1 occurs infrequently after solid organ transplantation, even in endemic regions with high seroprevalence [38, $41,42]$. Shirai et al. reviewed the courses of nine HTLV-1positive patients who underwent renal transplantation with basiliximab (anti-CD25) induction together with corticosteroids, mycophenolate mofetil, and cyclosporine or tacrolimus. No patient developed ATL or HAM during follow-up of approximately 5 years, although one patient died of aspiration pneumonia 17 days after transplantation [48]. A previous study also found no cases of ATL in 16 HTLV-1-positive kidney transplant recipients after up to 10 years of observation, at which point patient survival was $81 \%$. Patient and graft survival were not significantly different from HTLV-1 negative patients [49]. Smaller reports from western Japan (10 patients with up to 17 years of follow-up) and Iran (10 patients with up to 6 years of follow-up) presented similar findings [50, 51].

While screening of donors may prevent the transmission of HTLV-1 to recipients, the demand for organs may override this concern, even in highly endemic areas such as certain regions of Japan. In regions with low rates of infection, screening of all donors generates many false positives, resulting in delays in transplantation or the loss of potential organs for donation. Following the three cases of donor-derived HTLV-1 infection in Spain, 2870 potential organ donors and recipients were screened for antibodies to HTLV-1, including 1079 immigrants. Only five patients tested positive (confirmed by Western blot), and all of them were immigrants from South America or Africa [52]. The practice of universal HTLV-1 screening is no longer recommended by the United States Organ Procurement and Transplantation Network (OPTN) [37, 53]. However, targeted screening for HTLV-1/2 seropositivity by organ procurement organizations (OPO) may be encouraged in high-risk living and deceased donors based on local prevalence data $[43,54]$.

HSCT has been used in the treatment of ATL in HTLV-1positive patients, but since leukemia is a known complication of HTLV-1 infection, it can be asked if HSCT is safe and effective in such patients. Near relatives are the preferred sources of stem cells for transplantation, but in endemic areas, such individuals are also frequently infected with this retrovirus. The largest study addressing this question involved a retrospective analysis of data from three centers in Japan. In this study, 386 patients with ATL underwent allogeneic HSCT with a 3-year survival rate of $33 \%$. Unfortunately, those who received their transplant from a related HTLV-1-positive donor had a higher risk of diseaseassociated mortality relative to those whose related donor 
was HTLV-1 negative. HSCT recipients in complete remission at the time of transplantation had a higher rate of survival compared to patients not in complete remission $(51 \%$ versus $26 \%$ ). These results likely account for the finding that patients who received an HSCT from matched unrelated donors did as well as those from matched related donors (3-year survival, 39\% versus 41\%) [55]. No proven effective therapy for HAM exists. Some experts suggest antiviral prophylaxis with zidovudine and raltegravir, but antiviral therapy drugs are generally believed to have little effect on HTLV-1 because it is a cell-associated virus and proviral load is predominantly maintained by cell division of infected cells rather than free viral replication. Furthermore, definitive long-term benefits of interferon and corticosteroids have yet to be established [43].

\section{Rabies Virus}

Rabies virus is a member of the Rhabdoviridae family of RNA viruses and is one of seven species belonging to the genus Lyssavirus. All of these viruses except for Lagos bat virus have resulted in fatal human disease, but at this time, only rabies has been reported in the transplant population [56]. Rabies virus is typically acquired in humans through the bite of an infected animal. It is estimated that over 55,000 cases occur annually, worldwide, and most result from the bite of an infected dog $[56,57]$. In countries where canine vaccination is routine, bites from insectivorous bats have emerged as the most common source [57]. Rabies infection results in an encephalitis that is nearly universally fatal unless the patient has been vaccinated or receives postexposure prophylaxis (PEP). Limited data suggest that some individuals can survive rabies exposure without intervention, including a single case in the United States and serologic data from humans in the Peruvian Amazon, but these cases appear to be rare [58, 59].

Sixteen cases of rabies have been reported in transplant recipients, and to date, all of these cases have been transmitted through the transplanted tissue or organ (Table 45.1) [60-70]. Houff et al. first reported the transmission of rabies through a corneal graft in 1979 [66]. Since that time, eight other cases of rabies transmission have occurred through corneal transplantation. In seven of these nine cases, the cornea recipients presented with neurological symptoms within 40 days of their surgery and died soon after admission. Symptoms often included significant pain involving the eye that received the transplant [61, 62, 65-67]. In a case from France, reported in 1981, a patient exposed to rabies through corneal transplant survived after receiving PEP on the first postoperative day [70]. A second corneal transplant recipient, documented in a report from India, received partial PEP but then refused further treatment. He developed rabies 9 months after transplant and died shortly thereafter [67].
Three clusters of rabies cases have occurred following solid organ transplantation. The first four cases occurred in Texas in 2004 [63, 64, 69]. Rabies developed following the transplantation of the liver, both kidneys, and an iliac artery graft from an Arkansas man who died after being diagnosed with a subarachnoid hemorrhage. All four patients developed encephalitis within 30 days of transplantation and died between 7 and 23 days later. The diagnosis was confirmed by serology in the three recipients, immunohistochemistry (IHC) staining of pathological samples, and viral isolation in cell culture. During the follow-up investigation, it was determined that the donor had been bitten by a bat shortly before organ donation [69].

The second cluster of cases occurred in Germany in 2005 but was not widely published until 2010 [71-73]. Six patients were potentially exposed to rabies virus following the death of a 26-year-old woman, who died after presenting with altered mental status. She had reportedly consumed cocaine, amphetamines, and MDMA before her admission, developed cerebral edema, and was declared brain dead. During a contact investigation after the report of cases, it was discovered that she had been bitten by a dog on a recent trip to India. PEP was administered to all six transplant recipients (lung, liver, kidney, kidney-pancreas, and both corneas), though not until at least 45 days after transplantation. The recipients of lung, kidney, and kidney-pancreas transplants died of rabies. Antiviral treatment was administered (with ribavirin and interferon) in these three cases as well as in the case of the liver transplant recipient. The lung recipient died on posttransplantation day 49 despite the initiation of deep sedation with ketamine and midazolam. The kidney transplant recipient died on day 52 despite the addition of amantadine but not deep sedation. The kidney-pancreas recipient was also treated with deep sedation starting with midazolam followed by ketamine and phenobarbital. Brain death was declared after 9 weeks and supportive measures discontinued. The liver transplant recipient had been vaccinated against rabies over 20 years before transplantation and never developed disease [71, 72]. Both corneal grafts were explanted, but rabies virus was not detected in either cornea by RT-PCR. It has been suggested that the lack of rabies in these corneal grafts was the result of the limited excision procedure performed such as subcorneal complex excision rather than enucleation and the prolonged storage of the grafts prior to transplant for 5 days [72, 73].

In 2013, another case of transplant-transmitted rabies was identified in the United States. Signs and symptoms of rabies developed in a deceased-donor kidney recipient, a Maryland native, 17 months after transplantation, who ultimately died from rabies 3 weeks after hospitalization. Given lack of epidemiologic risk factors, an exploration of donor transmission was sought. In addition to a clinical presentation consistent with rabies in the organ donor, a raccoon rabies virus variant 
more than $99.9 \%$ identical across the entire $\mathrm{N}$ gene was identified in both the organ donor and the infected recipient. The genetic sequence was also closely associated with a raccoon variant circulating in North Carolina, the donor's state of residence [74]. Three unvaccinated recipients of organs (kidney, liver, and heart) from the same donor were asymptomatic when rabies was diagnosed in the donor. PEP with rabies vaccination and immunoglobulin was initiated in these asymptomatic organ transplant recipients, and protective neutralizing antibodies developed in all three [75].

As mentioned previously, the management of rabies focuses on prevention either with vaccination in high-risk patients or PEP following an animal bite. Three individuals have apparently recovered from rabies (diagnosed by antibody testing) without receiving either intervention. These have all been young women (aged 8, 15, and 17), and two patients received treatment with what is now called the Milwaukee protocol (named after Milwaukee, WI), which includes a prolonged therapeutic coma, antiviral therapy, management of vasospasm, and avoidance of prophylaxis $[58,76,77]$. To date, 30 patients have received the Milwaukee protocol, but only one other patient has survived to hospital discharge [78, 79]. This patient had received partial PEP, however [78]. In two reports (one case report and a case series of eight patients), transplant recipients who received rabies PEP appeared to mount an adequate response (antibody titers of $0.5 \mathrm{IU} / \mathrm{mL}$ ), though titers were lower than those seen in immunocompetent patients [80-82]. RodriguezRomo et al. reported the case of a kidney transplant recipient who received two courses of PEP after being bitten by a rabid dog. Following the first course, adequate antibody titers developed but then declined. A second PEP course was administered along with a reduction in immunosuppression; he maintained an adequate antibody level and remained asymptomatic [81]. Taken together, these data indicate that rabies vaccination can be effective, even after transplantation, and PEP may be safe and effective in transplant recipients.

\section{Lymphocytic Choriomeningitis Virus and the Arenaviridae}

Lymphocytic choriomeningitis virus (LCMV) is a member of the Old World complex of Arenaviridae, a family of viruses that also contains important hemorrhagic fever pathogens endemic in Africa and South America. LCMV was the first isolated arenavirus, identified in 1933 during an outbreak of St. Louis encephalitis [83]. Infection with LCMV in the immunocompetent host is often mild or asymptomatic. Symptomatic infections present as aseptic meningitis, but the mortality in immunocompetent patients is $<1 \%$. In the largest recorded outbreak, 181 cases were documented in the
United States associated with pet hamsters. While 46 patients were hospitalized, no one died [83-85].

In contrast to the clinical course of infection in immunocompetent patients, five clusters of cases following LCMV transmission through organ transplantation (including 17 cases and 12 deaths) document the ability of this pathogen to cause severe disease in transplant recipients (Table 45.1) [13, 33, 86-88]. Another cluster of cases involved the transmission of a newly identified arenavirus in Australia (three patients, all of whom died) [33]. As in rabies infections documented in transplant recipients, all of these cases resulted from human-to-human transmission through organ transplantation [13, 33, 86, 87]. At this time, cases acquired following transplant by exposure to rodents and their excreta have not been described. Also, cases have not been described in the HSCT population.

All five reported case clusters of LCMV infection occurred in SOT recipients in the United States (ten kidney, four liver, and three lung transplants). The first set of cases took place in 2003 in Wisconsin (four cases, four deaths), followed by clusters in 2005 in Massachusetts and Rhode Island (four cases, three deaths), 2008 in Massachusetts (two cases, two deaths), 2011 in Arkansas (four cases, two deaths), and 2013 in Iowa [13, 86-88]. Symptoms developed between 2 and 23 days posttransplant and included fever, abdominal pain, nausea, diarrhea, and altered mental status occasionally accompanied by seizures. A number of patients also developed a peri-incisional rash and tenderness. Laboratory findings included increased transaminases and creatinine. Both leucopenia and leukocytosis occurred. CSF findings included elevated protein (often marked), normal to low glucose, and a mild pleocytosis. The diagnosis of LCMV was confirmed in all patients using IHC on tissue samples or RT-PCR on tissue and serum samples. Serology was performed less frequently and was often negative. Bronchopneumonia or diffuse alveolar damage and hepatic inflammation or necrosis were the most common findings at autopsy [13, 86, 87, 89].

Five patients survived LCMV infection following SOT, including four kidney transplant recipients and a single liver recipient. One kidney transplant patient received treatment with ribavirin starting on posttransplant day 26 (2005 cluster) and survived, though a second kidney transplant recipient was treated with ribavirin (2008 cluster, starting 6 weeks posttransplant) and died $[13,86]$. Similarly, in the 2013 cluster, all three recipients received ribavirin therapy, and two also received intravenous immunoglobulin starting 6 weeks posttransplant, with survival in the two kidney recipients and death in the liver transplant recipient [88]. The two other survivors (2011 cluster) recovered without antiviral therapy [87]. Ribavirin has been shown to be clinically effective in the early treatment of Lassa fever, a related Old World arenavirus, but data for efficacy in the treatment of LCMV is lacking [90]. Four corneal transplant recipients were also 
potentially exposed to LCMV in these clusters, though none of them developed symptoms or seroconverted (two recipients in 2005 and a single recipient in 2011). The second cornea removed from the 2011 donor was never transplanted. This tissue tested negative for LCMV by IHC and RT-PCR $[13,87]$.

Contact investigation following these cases revealed exposure to rodents for two of the donors: a pet hamster (2005 donor) and rodent infestation of the home (2011 donor) [13, 87]. No definitive evidence of rodent exposure was discovered for the 2013 donor, although he had spent substantial time outside along the Mississippi River. Three of the donors also had positive LCMV testing: detectable IgM and $\mathrm{IgG}$ in archived serum from the day before death (2008 donor), a positive RT-PCR from a single lymph node (2011 donor), and a positive RT-PCR from aortic endothelial cells (2013 donor) [86-88]. Investigation into the 2003 donor revealed no clear exposure history and serology, viral culture, and IHC performed on other tissues collected at the time of donation were all negative $[13,91]$. Likewise, all diagnostic testing (including RT-PCR) performed on stored samples from the 2005 donor was negative, and all further testing performed on samples from the 2011 donor was negative (including other lymph nodes) [13, 87]. It has been advised that immunocompromised patients avoid contact with rodents, including pets [92, 93]. While this recommendation seems intuitive, this was not the mode of acquisition in these outbreaks, and it is unclear to what extent this will prevent future LCMV cases in transplant recipients.

An additional cluster of arenavirus cases occurred after the transplantation of the kidneys and liver from a single donor to three recipients in Australia in 2007. Patients developed fever, altered mental status, pulmonary infiltrates, and graft rejection soon after transplant, and they died between 29 and 36 days posttransplant. While their clinical course is not discussed in great detail, it sounds similar to that described for LCMV. The agent was identified by nextgeneration sequencing (Roche, 454 pyrosequencing) as Dandenong virus following random primer amplification. Sequences were consistent with an arenavirus, though certain segments were closest to LCMV and others more closely resembled Kodoko virus (isolated in African wild mice) [33].

It has been noted that the clinical disease caused by LCMV and this newly identified arenavirus are more similar to the severe illnesses caused by the other Old World arenaviruses, Lassa and Lujo viruses, and the New World arenaviruses such as Junin, Machupo, and Guanarito viruses [91]. Infection with any of these pathogens can result in a viral hemorrhagic fever with varying degrees of encephalopathy $[83,90]$. Cases of Lassa, Lujo, and New World arenavirus infections have not been described in immunocompromised patients, however. This absence of reporting may result from the relatively defined areas of endemicity for each virus as well as the limited number of transplants that are performed in those regions. Another possible explanation may stem from the unusual mode of transmission that leads to severe LCMV infection after SOT.

\section{Human Bocavirus and Parvovirus 4}

Human bocavirus (HBoV) and Parvovirus 4 (PARV4) are newly identified members of the Parvoviridae family of DNA viruses, subfamily Parvovirnae. Prior to their discovery, the only parvovirus known to infect humans was parvovirus B19. Both of these agents were identified in 2005, though there is a greater amount of clinical information on HBoV currently than PARV4 [27, 28, 94].

$\mathrm{HBoV}$ was initially detected in the nasopharyngeal (NP) aspirates of children with respiratory tract infections. Allander et al. randomly amplified DNA and RNA from these samples, followed by cloning and sequencing. This identified sequences similar to members of the genus Bocavirus, named for the type species bovine parvovirus and canine minute virus. They then showed that 17 pediatric patients (of 540 screened) had HBoV detectable by PCR, and in 14 of these patients, HBoV was the only pathogen detected. All patients had been admitted with respiratory distress and ten had fevers. The virus was also predominantly detected in the winter months (14 of 17) [28].

Since the original study, a number of reports have confirmed the association between $\mathrm{HBoV}$ detection and respiratory tract infections, along with the seasonality of detection [95-102]. The establishment of HBoV as a pathogen, however, has been complicated by the high rates of detection of co-pathogens along with $\mathrm{HBoV}$ (up to $90 \%$ ), detection of the virus in asymptomatic patients $(43 \%$ in one study from Canada), and significant difference in the study design of published reports, including different methods of sample collection (NP swab, NP aspirate, or bronchoalveolar lavage) and the extent to which other pathogens were excluded [36, 97, 100]. It does appear that HBoV causes a subset of respiratory tract infections, particularly among infants and young children ( $<2$ years of age), and the use of quantitative PCR may be a means to identify these patients. A $5.7 \%$ prevalence of $\mathrm{HBoV}$ has been reported from testing over $1800 \mathrm{NP}$ swabs from healthy children presenting with a respiratory illness over a 3-year period [103]. In a separate study by Allander et al., patients with high $\mathrm{HBoV}$ viral loads $\left(>10^{4}\right.$ copies $/ \mathrm{mL}$ ) in NP aspirates were more likely to have an isolated $\mathrm{HBoV}$ infection (though 18 of 28 patients still had another pathogen detected) and often had concomitant viremia detectable by PCR [95]. One study also reported an association between high $\mathrm{HBoV}$ viral loads in NP aspirates with longer duration of hospitalization in healthy pediatric children presenting with a respiratory illness [103]. The detection of $\mathrm{HBoV}$ in 
the blood is not necessarily surprising as other parvoviruses (B19 and PARV4) are also detected in this compartment. HBoV DNA has also been detected from stool, though its potential as a gastrointestinal pathogen is unclear [102].

The incidence and clinical manifestations of $\mathrm{HBoV}$ infections in the immunocompromised host have not been established (Table 45.1). In 2007, Schenk et al. reported the case of an HSCT recipient with disseminated $\mathrm{HBoV}$ infection. The patient was a 4-year-old boy who underwent HSCT and had a complicated hospital course including persistent fevers, which improved but did not completely resolve upon neutrophil engraftment, a lower respiratory tract infection, and diarrhea. $\mathrm{HBoV}$ was detected repeatedly from NP aspirates, serum, and stool, though its role in this case is complicated by the co-detection of rhinovirus from an NP aspirate, CMV reactivation, and grade I GVHD of the skin (no mention of path from the GI tract) [104]. In 2011, the same group reported on three more cases of immunocompromised patients (along with the case from 2007) with repeatedly positive tests for $\mathrm{HBoV}$. These patients had virus detectable after weeks of isolation, often during the summer months, which supports the hypothesis that $\mathrm{HBoV}$ may establish latency and reactivate in the setting of a coinfection or impaired immunity [105]. Severe diarrhea was also reported in a 9-year-old transplant recipient (both liver and HSCT) associated with detectable $\mathrm{HBoV}$ in plasma and stool [106]. Other studies evaluating the role of $\mathrm{HBoV}$ as a respiratory pathogen in immunocompromised adults have detected the virus at low levels (or not at all) and have not documented a difference in outcomes between immunocompromised patients and immunocompetent controls [107-109].

Many significant questions remain regarding the significance of $\mathrm{HBoV}$ in the transplant population, both pediatric and adult. One seroepidemiologic study out of Japan showed that between $94 \%$ and $100 \%$ of individuals have been exposed to HBoV by 6 years of age [110]. If this virus establishes latency, most transplant recipients will be at risk to develop reactivation, but whether that results in disease or is simply a marker of severe immune suppression has yet to be determined. The reporting of $\mathrm{HBoV}$ will no doubt increase. There are a number of published PCR assays to use for detection, and at least one platform for multiplex respiratory pathogen detection includes $\mathrm{HBoV}$ in a panel of 21 agents $[36,111]$. There is no specific antiviral treatment for $\mathrm{HBoV}$ at this time.

Much less clinical information on PARV4 exists. This virus was originally identified by SISPA from the serum of 1 of 25 patients presenting with an unidentified "viral syndrome" [27]. The virus has since been detected in a high percentage of patients who use IV drugs $(30 \%)$ and patients with HIV-HCV co-infection $(95 \%)$ [112, 113]. The clinical significance of these infections is unclear, though PARV4 may be associated with symptomatic early HIV infection
[113]. One report also documents two cases of encephalitis of unclear etiology in children (2 and 3 years of age) where PARV4 DNA was detected in the CSF [114]. Studies in transplant recipients have documented PARV4 in 5 of 164 renal transplant recipients and 14 of 104 lung transplant recipients (Table 45.1). No associations with clinical outcome have been identified $[112,115]$.

\section{Enterovirus D-68}

Enterovirus D-68 (EV-D68) belongs to the family Picornaviridae and is the causative agent of an outbreak of severe respiratory illness in 2014 that began in the United States and spread to several countries around the world. EVD68 was first identified in 1962 in four children suffering from pneumonia and bronchiolitis and, prior to 2014, detected in only a small number of patients [116]. The 2014 outbreak began concurrently in Kansas City, MO, and Chicago, IL, where an increase in hospitalizations for severe respiratory illness was noted in pediatric patients. Multiplex PCR assays detected an increase in rhinovirus/enterovirus in nasopharyngeal specimens. Evaluation by the CDC found 19 of 22 specimens from Kansas City and 11 of 14 specimens from Chicago positive for EV-D68. Of these 30 patients, 29 (96.7\%) were admitted to the ICU and 6 (20.0\%) required mechanical ventilation [117]. By the end of 2014, over 1100 cases of respiratory illness caused by EV-D68 had been reported in the United States, predominantly among children. Subsequently, more than 2000 cases of respiratory illness were attributed to EV-D68 in 20 countries worldwide [118, 119].

Though the manifestations of EV-D68 can be severe, EVD68 more commonly causes an upper respiratory tract infection that does not require hospitalization. Factors that predispose to milder disease are incompletely understood, though several studies report asthma as a risk factor for ICU admission and need for mechanical ventilation [118, 120]. Concurrent with the respiratory outbreak, clusters of children with acute flaccid paralysis and severe neurologic disease were observed in the United States and Europe and attributed to EV-D68 given the temporal relationship of symptoms and detection of the virus in pharyngeal swabs [121]. EV-D68 has since been linked with acute paralytic poliomyelitis, encephalitis, myelitis, encephalomyelitis, or acute transverse myelitis [119]. As no specific vaccine or antiviral for EV-D68 exists, treatment of children with EV-D68 is mainly supportive and focused on symptom relief for fever and respiratory support if needed.

Few studies have evaluated the extent of EV-D68 infection in immunocompromised patients. Eight cases of EV-D68 in hematologic malignancy or HSCT recipients were found in one study, which retrospectively tested for the 
presence of the virus in respiratory samples $(n=506)$ that had tested positive for human rhinovirus (HRV) or negative for all respiratory viruses in a multiplex panel collected over a 3-month period. Thirteen $(11.5 \%)$ cases originally identified as HRV were subsequently characterized as EV-D68 with a specific PCR assay, highlighting the limited specificity of HRV primers and the potential for inaccurate diagnosis. Furthermore, of the 393 cases initially negative for all respiratory viruses, $8(2 \%)$ were presumptive EV-D68. This has implications for infection control as patients with negative tests results would likely be removed from droplet isolation and theoretically could result in person-to-person transmission particularly among immunocompromised patients. The eight cases of EVD-68 in hematologic malignancy or HSCT recipients (51-1833 days from transplant) developed symptoms ranging from mild upper respiratory tract infection to respiratory failure [122]. Cases were not limited to children, as all were in immunocompromised adults aged 22-69 years old. At this time, cases of EV-D68 in solid organ transplants have yet to be reported in the literature.

\section{Measles, Mumps, and the Paramyxoviridae}

The family Paramyxoviridae contains a number of significant human pathogens and is divided into two subfamilies, Paramyxovirinae and Pneumovirinae. The major pathogens within the Pneumonvirinae, respiratory syncytial virus (RSV) and human metapneumovirus (hMPV), are discussed in detail elsewhere in this text. Paramyxovirinae contains five genera and includes measles (Morbillivirus) and mumps (Rubulavirus), the emerging pathogens nipah and hendra (Henipavirus), as well as the avian pathogen, avian paramyxovirus 1 (APMV-1, also known as Newcastle disease virus; Avulavirus). Measles and mumps are not typically considered emerging pathogens. However, the potential to cause severe disease in transplant recipients as well as the recent rise in incidence for both agents brings them into consideration here [123-131]. Nipah, hendra, and APMV-1 will also be discussed briefly.

Measles and mumps are both vaccine preventable illnesses and following the introduction of the MMR vaccine in 1967, there was a marked decrease in the incidence of these diseases in developed countries [125]. However, immunity can wane over time, even after the recommended two dose series in the immunocompetent patient. This decline in humoral immunity has been well documented in the transplant population, and even following repeat vaccination, response rates are suboptimal [132-135]. Repeat MMR vaccination posttransplant appears to be safe, and this topic will be covered in detail in a later chapter [133-135].
Severe disease in transplant recipients has more often been reported as a result of measles infection than mumps. The most significant manifestation of measles in this patient population is subacute measles encephalitis (SME, also reported as immunosuppressive measles encephalitis or measles inclusion body encephalitis), but severe cases of pneumonia and one case of liver transplant rejection possibly resulting from measles have also been reported (Table 45.1) [127, 129, 130, 136-142]. SME was originally documented in patients immunocompromised from chemotherapy or malignancy, and the disease was first reported in a renal transplant recipient in 1979 [127]. It has since been reported in other renal transplant recipients, though not always confirmed by IHC staining or RT-PCR, and a single patient following HSCT [129, 136, 141, 143]. Patients with SME may initially present with an illness compatible with measles, including fever, conjunctivitis, and a rash, though this is not consistent and typically is only recognized as measles in retrospect [127, 136, 139, 141]. Patients typically improve but then re-present with altered mental status and seizures between 2 weeks and 4 months after their initial illness. In a review of the literature, the range was 1-7 months, but this included predominantly nontransplant patients [129, 136, 139, 141]. At the time of admission for seizures, fevers are particularly uncommon, and CT imaging and CSF analysis are often normal. The first imaging changes are seen by MRI with increased signal intensity on FLAIR. The clinical course is one of deteriorating mental status and worsening seizures refractory to anti-epileptic drugs [127, 129, 136, 139]. Four of six transplant cases of SME died. The two survivors were reported in 2006 by Turner et al. Both cases occurred in pediatric renal transplant recipients, 6 and 11 years out from transplant. They both received one dose of IVIG and a course of IV ribavirin. Both of them survived, though both had significant neurological deficits [141]. A single case of SME occurred in a previously healthy boy following MMR vaccination, though during admission, he was found to have a primary immune deficiency [144].

The incidence of severe measles in transplant recipients is unclear as most of the data comes from case reports and reviews of the literature. In an attempt to answer this question, Machado et al. evaluated 156 HSCT recipients during the 1997 outbreak of measles in Sao Paolo. These investigators identified eight cases among 54 patients deemed to be susceptible (based on an $\mathrm{IgG} \leq 100 \mathrm{mIU} / \mathrm{mL}$ ), and notably, only one of them had severe disease, manifested as interstitial pneumonia. All eight patients survived [138]. It has been noted that the case definition, requiring a serological response (appearance of $\operatorname{IgM}$ or rise in $\mathrm{IgG}$ ), may be too restrictive for HSCT recipients, resulting in a number of missed cases [145]. A second, short report by Lee et al. documented a fatal case of pneumonia in an HSCT recipient clinically diagnosed with measles during an outbreak in Korea from 2000 
to 2001. At their center, they presumptively diagnosed 16 HSCT recipients with measles (methods not specified), with this as the only case of severe disease. The patient who died of pneumonia never developed detectable IgM or IgG [137]. The incidence of measles in SOT and HSCT recipients remains unclear, though given the 222 cases of measles in the United States and tens of thousands of cases in Europe in 2011 , it is likely under reported [128, 131].

Five cases of posttransplant mumps infection have been documented, including three renal transplant recipients and two HSCT recipients (Table 45.1) [123, 124, 146-148]. The three renal transplant patients developed parotid gland swelling. Two patients showed involvement of their graft: one in a patient with a failed graft already on dialysis and the second with a previously functioning graft who developed tubulointerstitial nephritis and permanent graft failure. This second patient also developed orchitis and vestibular neuronitis with persistent vertigo after recovery. All three patients survived [123, 146, 147]. Both cases in the HSCT literature document fatal encephalitis in young patients with severe combined immunodeficiency treated with HSCT. The first patient was a 16-month-old infant who developed meningoencephalitis and seizures prior to HSCT and deteriorated rapidly after transplant. Mumps was isolated in culture from urine, blood, and CSF. The infant had been vaccinated for mumps several months prior, and the authors suggest the vaccine strain as the potential cause of infection [124]. The second patient was a 19-year-old who developed subacute encephalomyelitis from a wild-type mumps strain 2 years after HSCT. Infection occurred during an outbreak of mumps in England and Wales in 2004 and 2005 [148].

APMV-1 causes lethal infections in birds and has been tested as a potential agent for virotherapy in certain malignancies [149]. Cases in humans have rarely been documented and typically involve an acute, self-limited conjunctivitis, often in poultry workers. In 2007, Goebel et al. reported a case of pneumonia in a 42-year-old HSCT recipient where APMV-1 was isolated in culture from bronchoalveolar lavage fluid, a lung biopsy, stool, and urine (identity confirmed by sequencing; Table 45.2). The patient died after 24 days, and IHC was consistent with APMV-1 infection. No other pathogens were isolated, though the patient was on broad spectrum antibiotics at the time of bronchoscopy [150].

Nipah and hendra viruses (and the recently identified Cedar virus, which will not be discussed further) comprise the genus Henipavirus and were identified in the 1990s as causes of encephalitis [151-153]. Old World fruit bats serve as the natural host for nipah and hendra, but these pathogens are notable among the Paramyxoviridae for their ability to infect a wide range of hosts, including pigs, horses, and humans. Hendra has been transmitted from horses to their handlers, and nipah has been transmitted from pigs and bats to humans [152, 154]. Human-to-human spread of nipah has also been documented in recent outbreaks [154-156]. Infection resulting from either virus can result in severe respiratory tract disease, encephalitis, or both. In a series of 92 cases of encephalitis from Bangladesh, $69 \%$ of patients also had respiratory difficulty, though this rate was higher than that seen in a series from Malaysia $(21 \%)$ [157, 158]. Mortality from encephalitis has ranged from $30 \%$ to $70 \%$ in different series, and residual neurological deficits can persist in survivors $[157,158]$. An unusual feature of infection with either of these viruses is the occurrence of relapsing or lateonset encephalitis that has been documented to occur up to 22 months after initial presentation and still carries a high mortality [159]. Treatment remains supportive. In the large series reported to date, which involve nipah virus, there have not been documented cases involving transplant recipients or immunocompromised hosts, though the comorbid illnesses of patients included in these series have not been fully described [157, 158].

\section{Poxviridae}

Poxviridae is a family of large DNA viruses that includes four genera (among many) of viruses with the potential to infect humans: Orthopoxvirus (including variola), Molluscipoxvirus (including molluscum contagiosum virus), Parapoxvirus, and Yatapoxvirus. Molluscum contagiosum is widely recognized, and in the immunocompromised patient, molluscum contagiosum virus infection can cause an eruption of large and widespread skin lesions. We will not discuss this agent further in this chapter.

Orf virus, a Parapoxvirus, is a well-known pathogen in sheep, particularly young lambs, and causes papulovesicular lesions in the mouth and groin of affected animals [160, 161]. Orf lesions, also known as ecthyma contagiosum, also occur in humans. These lesions tend to be solitary and occur on the extremities of individuals who work with infected sheep. In the immunocompetent patient, these lesions are self-limited and tend to heal over 1-2 months [160, 161]. In transplant and immunocompromised patients, however, a number of cases of recurrent and giant orf lesions have been reported (Table 45.1) [160-164]. These lesions can be $5 \mathrm{~cm}$ or more in diameter and have been confined to the hand or forearm. All patients reported contact with sheep. Patients have undergone excision with skin grafting or even amputation when these lesions are not diagnosed correctly, but even with such aggressive treatment, lesions tend to recur after a few weeks to months [160, 162-164]. A single patient also developed a new lesion at the skin-graft donor site [164]. While no standard treatment exists, three case-reports document responses in renal transplant patients using cryotherapy, cidofovir cream, or imiquimod (a single case for each treatment) $[161,163,164]$. The patients treated with cryotherapy 
and cidofovir required a second course of treatment but again responded well [161, 163].

Cases of human monkeypox, an Orthopoxvirus, were first recognized in 1970 during the vaccination campaigns to eradicate smallpox, though earlier cases may have been diagnosed as the clinically similar smallpox $[165,166]$. Outbreaks of disease continue in the Democratic Republic of the Congo and neighboring Sudan, and indeed, the incidence appears to be increasing after cessation of routine smallpox vaccination over 30 years ago [165-167]. In 2003, the first cases of monkeypox outside of Africa occurred in the Midwestern United States, with 37 confirmed cases associated with exposure to sick pet prairie dogs that in turn had been infected by rodents imported from West Africa [152, 166, 168]. Though fatal cases of monkeypox in Africa are well described, no fatalities were reported among these 37 patients [167-169]. Nine patients were described as having severe disease, including a single case each of encephalitis and respiratory distress, and five patients were hospitalized. One patient described in the series had received an HSCT, but they were not reported among the cases of severe disease and appear to have recovered fully (Table 45.2) [152, 166, 168].

A novel orthopoxvirus was recently identified to cause a rash illness in a renal transplant recipient who was 26 months posttransplantation. The patient developed a tender, erythematous, and indurated rash with development of vesiculopustular lesions on the right lateral chest wall. Multiple debridements failed to demonstrate the causative agent and were negative for HSV and VZV by IHC straining and acidfast and fungal organisms by special staining. A dense inflammatory infiltrate composed of lymphocytes, histiocytes, and focal eosinophils extending into the subcutaneous adipose tissue was consistently demonstrated on multiple specimens. Culture on human epithelial type 2 cells and BSC40 cells demonstrated viral cytopathic effects, but could not be further identified with standard evaluation. Viral DNA was then sequenced by next-generation sequencing. De novo assembly of the viral genome and phylogenetic analysis revealed a novel poxvirus most closely related to Yoka poxvirus, which was isolated from mosquitoes in the Central African Republic in 1972 during an ecologic survey. The patient had no travel outside of his community in upper New York state. The epidemiology of this novel pox virus is not known at this time; however this case serves as reminder that immunocompromised patients are prone to novel infectious diseases [170].

\section{Global Emerging Pathogens}

SOT and HSCT have become the treatments of choice for a large number of disease processes. Advancements in immune suppression and improvements in the management of oppor- tunistic infections have allowed a growing number of centers worldwide to perform such procedures. According to the Global Observatory on Donation and Transplantation, over 100,000 solid organ transplants were performed in 2013, including 80,000 kidney and 25,000 liver transplants. From 2000 to 2010, the number of countries performing kidney transplant increased from 33 to 84 . While the number of kidney transplants performed annually in the United States and Canada stayed relatively stable from 2005 to 2015 (16,48517,878 and 1049-1265, respectively), the total number performed in the Americas region nearly doubled (from 14,512 to 28,324). Countries that include endemic areas for many emerging infectious diseases are now performing a significant number of transplants (e.g. Brazil and India, which both performed around 5000 kidney transplants in 2010) [171]. In the following sections, we will briefly discuss a number of different emerging viral pathogens. To date, few of these have been documented in transplant recipients. With the marked increase in both SOT and HSCT, this will no doubt change, and we expect a corresponding increase in emerging viral infections in transplant hosts, both from known viruses and those yet to be identified.

\section{Dengue Virus, Zika, and the Flaviviruses}

Flaviviruses are single-stranded RNA viruses, and this genus contains a number of important human pathogens, including dengue virus (DENV), Zika virus (ZIKV), yellow fever virus (YFV), Japanese encephalitis virus (JEV), West Nile virus (WNV), St. Louis encephalitis virus, and tick-borne encephalitis virus (TBEV), among others. In this section, we will focus on DENV but also briefly discuss ZIKV, YFV, and case reports of USUV, an emerging avian pathogen in Africa and Europe [172]. Cases or case series of other flaviviruses have not been reported in the transplant literature, which may be partly explained by effective vaccines for both JEV and TBEV.

DENV is the most common vector-borne disease worldwide and has emerged as a significant pathogen in an increasing number of countries over the last 40 years [173]. Four serotypes of DENV exist (DENVs 1-4) and are transmitted by Aedes aegypti and Aedes albopictus mosquitoes. All have the potential to cause a range of clinical illness, from asymptomatic infection to classical dengue fever (DF) to severe dengue, including dengue hemorrhagic fever (DHF) and dengue shock syndrome (DSS). Infection with one serotype (primary infection) results in immunity to that serotype, but infection can occur with any of the remaining serotypes (secondary infection) [173]. Secondary infection has been shown to be a significant risk factor for the development of severe dengue, and this appears to result from both disadvantageous humoral and cellular immune responses (termed 
antibody-dependent enhancement and original antigenic sin, respectively) [174, 175]. Other factors are also important, such as the order of infection as well as the specific DENV strain $[176,177]$.

A number of reports have documented the occurrence of both DF and severe dengue in transplant recipients (Table 45.1) [178-187]. Two case series from Brazil (27 patients) and Singapore (6 cases) present a less severe picture of DENV infection in renal transplant patients [178, 182]. In the study from Brazil, eight patients had been hospitalized and one died of respiratory failure. Only a single patient developed DHF, and this person recovered [178]. The six patients in Singapore were identified on presentation to the hospital. Though all survived, the mean platelet count was 80,000 and 5 patients developed leucopenia. There were no cases of DHF or DSS [182]. All 33 patients in these 2 series had stable graft function.

Severe cases of dengue were reported from India in a series of eight renal transplant patients, who were diagnosed with DENV on admission to the hospital. Five patients developed DHF, and three patients developed DSS. All those in the latter group died [186]. Four other case reports in renal transplant recipients include three cases of DHF and a single, fatal case of DSS $[179,181,184,185]$. Though these represent a small number of cases, it is notable that four of the patients with severe dengue developed disease within 1 month of transplantation (two during their initial hospitalization), while all of the patients in the series from Brazil and Singapore developed their illness 3 months or more after transplant. Reports also document a single fatal case of DSS occurring in a liver transplant recipient (date of transplant not reported) and a fatal case of severe dengue 4 days after HSCT [180, 183] Most patients were diagnosed using NS1 protein detection or rapid IgM and IgG, and RT-PCR was less commonly performed. The serotypes, when reported, included DENVs 1, 3, and 4 [180, 183-185].

Human-to-human transmission of DENV as a result of organ transplantation has been documented. In one case of DENV transmission from a living donor to liver transplant recipient in India, the donor developed fevers, thrombocytopenia, and transaminitis 2 days after liver donation. Donor blood was positive for DENV NS1 antigen. The recipient developed a similar clinical presentation 5 days after transplantation and was also positive for DENV NS1 antigen. Both recipient and donor were treated with supportive measures and discharged after their full recovery 2-3 weeks after transplantation [188]. A case of donor-derived DENV transmission in HSCT has also been reported. In this report from Germany, the donor similarly developed clinical symptoms of DENV days after donation of peripheral blood stem cells to a recipient with acute myeloblastic leukemia and was only later noted to have returned from a trip to Sri Lanka. DENV NS1 antigen and PCR were positive in the donor. The recipi- ent was subsequently treated with IVIG; however, the recipient ultimately developed cardiopulmonary arrest and died 9 days posttransplant. Blood testing of the recipient also was positive by DENV NS1 antigen and PCR. Sequencing of virus showed genotype 1 infection with sequence similarity to circulating DEV 1 genotype 1 strains in Sri Lanka [189].

Emergence of ZIKV, another mosquito-borne flavivirus, was first reported in 2007 in the Federated States of Micronesia where an outbreak of febrile illness occurred that was characterized by rash, conjunctivitis, and arthralgias. By 2015, ZIKV spread throughout the Pacific Islands, continental South America and into Central America, the Caribbean, and Mexico. ZIKV is linked with outbreaks of GuillainBarre syndrome and devastating birth defects, most notably fetal microcephaly, from infection during pregnancy. Given the recency of the epidemic, the effects of ZIKV infection in transplant recipients are currently not known. The potential impact of any major viral infection on transplant outcomes can be significant with increased morbidity and mortality in transplant recipients who develop disease [190]. The full influence of ZIKV on transplantation remains to be determined.

YFV is closely related to DENV, exists in sub-Saharan Africa and South America, and is transmitted by the bite of infected Aedes species mosquitoes. To date, no cases of YFV have been reported in the transplant literature [191]. The YFV vaccine is effective, but it is live-attenuated and not currently recommended for transplant recipients. In one small study, 19 SOT recipients received the YFV vaccine inadvertently during outbreaks in Brazil. No severe AEs were reported, and the mean posttransplant time at vaccination was over 5 years [192]. Similarly, a patient with AML who started chemotherapy just 7 days after receiving YFV vaccination did not develop AEs despite detection of the 17D attenuated viral strain by RT-PCR in plasma samples for 15 days after vaccination. Interestingly, protective neutralizing antibodies were detected 1 month after the vaccine, indicating that memory B lymphocytes may have been preserved despite ablative bone marrow suppression [193].

Two case reports exist, both from Italy in 2009, of USUV causing encephalitis in immunocompromised patients [16, 23, 172]. The first report was of a woman with diffuse large B-cell lymphoma who presented with fever and a resting tremor. CSF was sent for a pan-flavivirus RT-PCR, and sequencing was consistent with USUV [23]. The second patient had TTP and was admitted with fevers and a headache. She developed fulminant liver failure and received a liver transplant (Table 45.2). Plasma drawn just before transplant gave a weak positive signal in a WNV RT-PCR. Flavivirus RT-PCR was then performed, and sequencing was consistent with USUV [16]. Both patients recovered, though had some residual neurological deficits. 


\section{Alphaviruses}

The alphaviruses are a genus of single-stranded, positivesense RNA viruses (within the Togaviridae family) that cause either encephalitis such as eastern, western, and Venezuelan equine encephalitis viruses or a systemic febrile illness with a rash and arthritis including Semliki Forest, Sindbis, O'nyong-nyong, Mayaro, Ross River, and Chikungunya viruses. In 2004, Chikungunya virus (CHIKV) re-emerged in Kenya and spread to countries around the Indian Ocean, including Reunion, a French overseas district, and India, resulting in millions of cases [194, 195]. Autochthonous spread was even detected in Italy in 2007 [196]. Symptomatic CHIKV infections result in a severe arthritis, which can persist for months following resolution of the fever and rash [197, 198]. Cases of meningoencephalitis and fatalities have been reported [199, 200]. Two cases of severe CHIKV infections in immunocompromised patients were reported by Kee et al., in 2010, including one patient taking an herbal medicine felt to contain steroids and a liver transplant recipient (Table 45.2). The liver transplant recipient presented with fever, headache, and abdominal complaints. IgM was positive for CHIKV, but IgG and serum RT-PCR remained negative (lumbar puncture was not performed). He recovered fully. Neither patient developed arthritis or arthralgias during the course of their infections [201]. A subsequent case of CHIKV infection in an HIVinfected kidney transplant recipient who had traveled to the Dominican Republic 4 years of transplantation reported an episode of arthritis lasting 2 months, which ultimately selfresolved [202]. In a second study, investigators tested corneal grafts from patients living in La Reunion during the 2005-2006 CHIKV outbreak. Twelve of 69 asymptomatic, potential donors were found to be viremic (3 patients) or IgM positive (11 patients, including 2 patients with viremia), and corneal grafts from 4 of these patients (all 3 viremic patients) had detectable CHIKV RNA on RT-PCR. While no cases of transplant-associated CHIKV transmission have been documented, researchers did show that transmission can occur by the ocular route in mice [203].

\section{Bunyaviridae}

Bunyaviridae is a family of segmented RNA viruses that includes a number of emerging pathogens, including Rift Valley fever virus (RVFV), the hantaviruses, Crimean-Congo hemorrhagic fever virus, and two newly identified phleboviruses, HYSV and Heartland virus. Bunyaviruses are vectorborne viruses, except for the hantaviruses, which are transmitted through aerosols from infected rodents. RVFV is an important livestock pathogen in Africa and causes outbreaks of severe human disease, often following periods of heavy rain. Many human infections are asymptomatic or result in a self-limited febrile illness, though cases of encephalitis and hemorrhagic fever are reported. Disease severity tends to be greater during large outbreaks, and mortality rates of up to $30 \%$ in symptomatic patients have been seen. Recently, this infection was seen for the first time in countries outside of Africa, causing outbreaks in Saudi Arabia and Yemen [204, 205]. To date, there have not been reported cases within the transplant community.

HYSV and Heartland virus have been described in the last 2 years, and clinical experience remains limited. HYSV is a tick-borne bunyavirus and was identified in patients in China presenting with fevers and thrombocytopenia without an identified cause [17]. A recent publication on the clinical course of 49 inpatients with confirmed HYSV documented a mortality of $16 \%$, which correlated with high viral loads on admission [206]. Heartland virus has been isolated from two patients in Missouri, United States, who were admitted with fevers, diarrhea, and thrombocytopenia. They both improved with supportive care [18]. Both of these viruses were initially isolated in cell culture before being further characterized by electron microscopy and sequencing, and they appear to be closely related members of the genus Phlebovirus [17, 18]. Given their recent identification, it is not unexpected that these infections have not been characterized in the transplant population.

The Hantavirus genus includes at least 23 related viruses that cause hemorrhagic fever with renal syndrome (HFRS) or hantavirus pulmonary syndrome (HPS). Three cases of hantavirus infection in immunocompromised patients, including a single case in a renal transplant recipient, have been reported (Table 45.2) [207-209]. All of these cases involved Old World hantaviruses that are associated with HFRS including Dobrava-Belgrade virus, one case, and Puumala virus, two cases. The renal transplant recipient, 18 months after transplantation, presented with 5 days of fevers, headache, and arthralgia. He developed oliguric renal failure and required 5 days of dialysis prior to return of normal urine output. He was treated with steroids for acute rejection, but given his presentation, he was also evaluated for other causes. IgM returned positive for Dobrava-Belgrade virus, and the patient made a full recovery [207]. The two cases of Puumala virus infection involved a patient with acute leukemia and one receiving anti-TNF therapy. Both patients did well, though interestingly, the patient with leukemia was felt to be infected through a platelet transfusion $[208,209]$. The treatment of hantavirus infections remains largely supportive. There is limited data for the use of ribavirin, which decreased mortality in a study of HFRS in China, reported in 1991 [210]. A trial of ribavirin in HPS was terminated early due to slow patient accrual. This study showed no improvement in the patients given ribavirin, though it was underpowered [211]. No benefit was seen in the use of oral prednisone in HFRS [212]. 


\section{Filoviridae}

Marburg and Ebola viruses are the only members of the Filoviridae family and are two of the most virulent human pathogens, causing outbreaks of hemorrhagic fever with mortality rates of up to $90 \%$. Except for the first identified outbreak of Marburg virus in 1967, when it was isolated from patients in Germany and Yugoslavia who had handled infected African green monkeys, these viruses have only caused hemorrhagic fever outbreaks in Africa. The largest Ebola outbreak recorded began in 2013 in West Africa (predominantly Liberia, Sierra Leone, and Guinea) and has resulted in over 28,000 cases and 11,000 deaths to date and include the transmission from individuals infected in West Africa to healthcare workers in the United States and Europe [213-215].

The incubation period for these viruses is 3-13 days. Patients then become acutely ill, developing high fevers and other nonspecific complaints such as malaise, nausea, vomiting, and diarrhea. Most patients develop a maculopapular rash, and they often develop hemorrhagic manifestations from multiple mucosal sites. Laboratory abnormalities are not diagnostic but include initial leucopenia, often followed by a leukocytosis, thrombocytopenia, increased transaminases (typically AST more than ALT), and prolonged prothrombin time [213]. Virus is detectable, using RT-PCR, antigen detection, or culture, in the blood and other body fluids at the time of presentation [213, 216, 217]. Care at this time is supportive along with infection control procedures including patient isolation. The majority of patients who die as a result of Marburg or Ebola do so within the first 2 weeks, and convalescent time for survivors is often prolonged [213]. Many long-term complications have been reported in survivors, with rheumatologic and ocular complaints most predominant. $50-75 \%$ of survivors report symmetric, polyarthritic arthralgias. Eye pain, conjunctivitis, photophobia, hyperlacrimation, uveitis, and loss of visual acuity also seem to be common with reports in as much as half of survivors in certain regions during the West Africa outbreak.

Though Marburg and Ebola infections have not been reported in the transplant population, likely due to the barriers to the establishment of robust transplant program in these countries, recognition of risk factors for Ebola among potential donors during outbreak periods may be of importance. Symptomatic patients have virus disseminated in multiple organs and body fluids, and transmission occurs via contact with infected fluids. Donor-derived infection may involve a donor who died of unrecognized Ebola or an infected but not yet symptomatic donor. Donors who have traveled to areas with significant Ebola activity, health-care workers working directly with Ebola, and others with direct exposure to a patient with proven Ebola infection in the prior 21 days should raise caution for possible donor-derived Ebola transmission [217].

\section{Xenotransplantation}

Acellular xenografts have been in use for decades, and porcine islet cell transplantation recently entered clinical trials, but the xenotransplantation of organs remains experimental and beyond the realm of clinical medicine [218]. The scientific and ethical questions surrounding the transplantation of organs, cells, and tissues from nonhuman species have generated an independent body of literature. The handling of these questions is beyond the scope of this text, and we will only briefly discuss some of the concerns regarding the transmission of viral zoonoses to human xenograft recipients.

The porcine endogenous retroviruses (so called PERVs) are incorporated in swine DNA and genetically acquired $[218,219]$. These viruses can be found in the genomes of all swine, and there is concern that they could infect transplant recipients, as human cells have been shown to be susceptible in vitro [219-224]. In a study using a pig-to-baboon model of SOT, PERV proviral DNA was found in the PBMCs of all ten animals, though viral RNA was not detected [223]. In studies of recipients of islet cell transplants, PERV transmission has not been documented, though in these studies, patients are rarely immunocompromised [224-226]. PERV transmission was not detected in liver allotransplant recipients who happened to be pig farmers [221]. If these infections do occur, their clinical significance still remains unclear.

Other viruses are also a concern in xenotransplantation. These include the porcine herpesviruses, porcine CMV (PCMV) and porcine lymphotropic herpesvirus (PLHV); HEV, particularly genotypes 3 and 4; and certain parvoviruses [218]. Many of these viral agents can be excluded from herds by careful breeding practices and frequent herd monitoring. A single study of islet cell transplant to human recipients did not detect PCMV or PLHV, which were also not detected in the herds prior to transplantation [225]. In the pig-to-baboon model of SOT, PCMV DNA was detected in two recipients and PLHV DNA was detected in six (of ten baboons). RNA was not detected for either of these viruses, supporting the conclusion that these were not productive infections. The outcome of these infections remains unclear, however, as the longest surviving recipient after transplantation was only 179 days [223].

\section{Prevention and Reporting}

The majority of viral infections discussed in this chapter appear to occur rarely in transplant recipients, though data are insufficient to determine the true incidence of disease. Measles, mumps, and yellow fever are vaccine-preventable illnesses, though these vaccines are all live-attenuated. Also, 
the response to vaccines in this patient population is lower than the response in immunocompetent patients. Donortransmitted rabies carries a dire prognosis, and though limited data exists, the use of PEP in transplant recipients appears safe.

Given their apparent rarity, screening for many of these diseases in organ donors cannot be recommended at this time. The examples of HTLV-1 and LCMV are illustrative of some of the difficulties involved with donor screening. In low-prevalence settings, HTLV-1 testing generates a large number of false-positive tests, and confirmatory testing can delay transplantation $[37,53]$. Hence, this is no longer required by the US OPTN [37, 53]. In the outbreak investigations for LCMV, only one of four donors had detectable antibodies. Indeed, RT-PCR from multiple samples failed to detect LCMV from one donor and yielded a positive result in a single lymph node (but not other samples) in another [13, 86, 87]. It seems prudent to obtain a comprehensive history of potential organ donors, including all recent exposures and travel, though it remains unclear how certain findings, such as rodent ownership, should affect one's status as an organ donor.

Reporting rare or unusual infections in transplant recipients, though retroactive, will help to identify agents for which more research is needed and screening may be warranted. At this time, expectations in the United States are for transplant centers to report unexpected potential or proven infections discovered after procurement of a donor organ to the OPTN Patient Safety System [227]. This remains a passive reporting system, however, and it is possible that events are missed if these infections are underdiagnosed or if symptoms are attributed to more common, and potentially coincident, posttransplant infections.

\section{References}

1. IOM. Executive summary. In: Lederberg JS, Shope RE, Oaks Jr SC, editors. Emerging infections: microbial threats to health in the United States. Washington, DC: National Academy Press; 1992.

2. Addressing emerging infectious disease threats: a prevention strategy for the United States. Executive summary. MMWR Recommendations and reports: Morb Mortal Wkly Rep Recommendations Reports / Centers for Disease Control 1994;43:1-18.

3. Woolhouse ME, Gowtage-Sequeria S. Host range and emerging and reemerging pathogens. Emerg Infect Dis. 2005;11:1842-7.

4. Kumar D. Emerging viruses in transplantation. Curr Opin Infect Dis. 2010;23:374-8.

5. Nishi SPE, Valentine VG, Duncan S. Emerging bacterial, fungal and viral respiratory infections in transplantation. Infect Dis Clin N Am. 2010;24:541-55.

6. Fischer SA. Emerging viruses in transplantation: there is more to infection after transplant than CMV and EBV. Transplantation. 2008;86:1327-39.

7. Boeckh M. The challenge of respiratory virus infections in hematopoietic cell transplant recipients. $\mathrm{Br} \mathrm{J}$ Haematol. 2008;143:455-67.
8. Renaud C, Campbell AP. Changing epidemiology of respiratory viral infections in hematopoietic cell transplant recipients and solid organ transplant recipients. Curr Opin Infect Dis. 2011;24:333-43.

9. Kotton CN. Zoonoses in solid-organ and hematopoietic stem cell transplant recipients. Clin Infect Dis. 2007;44:857-66.

10. Waggoner JJ, Soda EA, Deresinski S. Rare and emerging viral infections in transplant recipients. Clin Infect Dis. 2013;57(8):1182-8.

11. Razonable RR. Rare, unusual, and less common virus infections after organ transplantation. Curr Opin Organ Transplant. 2011;16:580-7.

12. Chatzidimitriou D, Gavriilaki E, Diza E. Hematopoietic cell transplantation and emerging viral infections. J Med Virol. 2010;82:528-38.

13. Fischer SA, Graham MB, Kuehnert MJ, et al. Transmission of lymphocytic choriomeningitis virus by organ transplantation. $\mathrm{N}$ Engl J Med. 2006;354:2235-49.

14. Tesh RB. A method for the isolation and identification of dengue viruses, using mosquito cell cultures. Am J Trop Med Hyg. 1979;28:1053-9.

15. Caliendo AM. Multiplex PCR and emerging technologies for the detection of respiratory pathogens. Clin Infect Dis. 2011;52(Suppl 4):S326-30.

16. Cavrini F, Baibani P, Longo G, et al. Usutu virus infection in a patient who underwent orthotropic liver transplantation, Italy, August-September 2009. Euro Surveill. 2009;14:19448.

17. Yu XJ, Liang MF, Zhang SY, et al. Fever with thrombocytopenia associated with a novel bunyavirus in China. N Engl J Med. 2011;364:1523-32.

18. McMullan LK, Folk SM, Kelly AJ, et al. A new phlebovirus associated with severe febrile illness in Missouri. N Engl J Med. 2012;367:834-41.

19. Delwart EL. Viral metagenomics. Rev Med Virol. 2007;17:115-31.

20. Wang D, Urisman A, Liu Y, et al. Viral discovery and sequence recovery using DNA microarrays. PLoS Biol. 2003;1:257-60.

21. Greninger AL, Chen EC, Sittler T, et al. A metagenomic analysis of pandemic influenza A (2009 H1N1) infection in patients from North America. PLoS One. 2010;5:e13381.

22. Mokili JL, Rohwer F, Dutilh BE. Metagenomics and future perspectives in virus discovery. Curr Opin Virol. 2011;2:63-77.

23. Pecorari M, Longo G, Gennari W, et al. First human case of Usutu virus neuroinvasive infection, Italy, August-September 2009. Euro Surveill. 2009;14:pii: 19446.

24. Li L, Delwart E. From orphan virus to pathogen: the path to the clinical lab. Curr Opin Virol. 2011;1:282-8.

25. Okamoto H. History of discoveries and pathogenicity of TT viruses. Curr Top Microbiol Immunol. 2009;331:1-20.

26. Reyes GR, Kim JP. Sequence-independent, single-primer amplification (SISPA) of complex DNA populations. Mol Cell Probes. 1991;5:473-81.

27. Jones MS, Kapoor A, Lukashov VV, Simmonds P, Hecht F, Delwart E. New DNA viruses identified in patients with acute viral infection syndrome. J Virol. 2005;79:8230-6.

28. Allander T, Tammi MT, Eriksson M, Bjerkner A, TiveljungLindell A, Andersson B. Cloning of a human parvovirus by molecular screening of respiratory tract samples. Proc Natl Acad Sci U S A. 2005;102:12891-6.

29. Su Z, Ning B, Fang H, Perkins R, Tong W, Shi L. Next-generation sequencing and its applications in molecular diagnostics. Expert Rev Mol Diagn. 2011;11:333-43.

30. Eid J, Fehr A, Gray J, et al. Real-time DNA sequencing from single polymerase molecules. Science. 2009;323:133-8.

31. Cheval J, Sauvage V, Frangeul L, et al. Evaluation of highthroughput sequencing for identifying known and unknown viruses in biological samples. J Clin Micobiol. 2011;49:3268-75. 
32. Yozwiak NL, Skewes-Cox P, Stenglein MD, Balmaseda A, Harris E, DeRisi JL. Virus identification in unknown tropical febrile illness cases using deep sequencing. PLoS Negl Trop Dis. 2012;6:e1485

33. Palacios G, Druce J, Du L, et al. A new arenavirus in a cluster of fatal transplant-associated diseases. $\mathrm{N}$ Engl $\mathrm{J}$ Med. 2008;358:991-8.

34. Sridhar S, To KK, Chan JF, Lau SK, Woo PC, Yuen KY. A systematic approach to novel virus discovery in emerging infectious disease outbreaks. J Mol Diagn. 2015;17:230-41.

35. Lipkin WI, Anthony SJ. Virus hunting. Virology. 2015;479-480:194-9.

36. Schildgen O, Muller A, Allander T, et al. Human bocavirus: passenger or pathogen in acute respiratory tract infections? Clin Microbiol Rev. 2008;21:291-304. table of contents

37. Network USOPaT. Guidance for HTLV-1 screening and confirmation in potential donors and reporting potential HTLV-1 infection, 2011 June 29. 2011.

38. Tsurumi H, Tani K, Tsuruta T, et al. Adult T-cell leukemia developing during immunosuppressive treatment in a renal transplant recipient. Am J Hematol. 1992;41:292-4.

39. Gout O, Baulac M, Gessain A, et al. Rapid development of myelopathy after HTLV-I infection acquired by transfusion during cardiac transplantation. N Engl J Med. 1990;322:383-8.

40. Yoshizumi T, Shirabe K, Ikegami T, et al. Impact of human T cell leukemia virus type 1 in living donor liver transplantation. Am J Transplant. 2012;12:1479-85.

41. Jenks PJ, Barrett WY, Raftery MJ, et al. Development of human T-cell lymphotropic virus type I-associated adult T-cell leukemia/ lymphoma during immunosuppressive treatment following renal transplantation. Clin Infect Dis. 1995;21:992-3.

42. Zanke BW, Rush DN, Jeffery JR, Israels LG. HTLV-1 T cell lymphoma in a cyclosporine-treated renal transplant patient. Transplantation. 1989;48:695-7.

43. Ramanan P, Deziel PJ, Norby SM, Yao JD, Garza I, Razonable RR. Donor-transmitted HTLV-1-associated myelopathy in a kidney transplant recipient--case report and literature review. Am J Transplant. 2014;14:2417-21.

44. Ramanan P, Deziel PJ, Norby SM, Yao JD, Garza I, Razonable RR. Donor-derived HTLV-1 associated myelopathy after transplantation: a call for targeted screening. Am J Transplant. 2015; $15: 1125$.

45. Cook LB, Melamed A, Demontis MA, et al. Rapid dissemination of human T-lymphotropic virus type 1 during primary infection in transplant recipients. Retrovirology. 2016;13:3.

46. Zarranz Imirizaldu JJ, Gomez Esteban JC, Rouco Axpe I, et al. Post-transplantation HTLV-1 myelopathy in three recipients from a single donor. J Neurol Neurosurg Psychiatry. 2003;74:1080-4.

47. Emmanouilides CE, Territo M. HTLV-I-associated myelopathy following allogeneic bone marrow transplantation. Bone Marrow Transplant. 1999;24:205-6.

48. Shirai H, Suzuki M, Tomita Y, et al. Renal transplantation in patients with human T-cell lymphotropic virus type 1 . Transplant Proc. 2012;44:83-6.

49. Tanabe K, Kitani R, Takahashi K, et al. Long-term results in human T-cell leukemia virus type 1-positive renal transplant recipients. Transplant Proc. 1998;30:3168-70.

50. Naghibi O, Nazemian F, Naghibi M, Ali Javidi DB. Prognosis of HTLV-1 positive renal transplant recipients in Iran. Saudi J Kidney Dis Transpl Saudi Arabia. 2011;22:670-4.

51. Nakamura N, Tamaru S, Ohshima K, Tanaka M, Arakaki Y, Miyauchi T. Prognosis of HTLV-I-positive renal transplant recipients. Transplant Proc. 2005;37:1779-82.

52. Toro C, Benito R, Aguilera A, et al. Infection with human T lymphotropic virus type I in organ transplant donors and recipients in Spain. J Med Virol. 2005;76:268-70.
53. Network USOPaT. Policy 2: minimum procurement standards for an organ procurement organization (OPO). 2012:7.

54. Tedla F, Brar A, John D, Sumrani N. Risk of transmission of human T-lymphotropic virus through transplant. Am J Transplant. 2015;15:1123-4.

55. Hishizawa M, Kanda J, Utsunomiya A, et al. Transplantation of allogeneic hematopoietic stem cells for adult T-cell leukemia: a nationwide retrospective study. Blood. 2010;116:1369-76.

56. Warrell MJ. Emerging aspects of rabies infection: with a special emphasis on children. Curr Opin Infect Dis. 2008;21:251-7.

57. De Serres G, Dallaire F, Cote M, Skowronski DM. Bat rabies in the United States and Canada from 1950 through 2007: human cases with and without bat contact. Clin Infect Dis. 2008;46:1329-37.

58. Centers for Disease Control and Prevention. Presumptive abortive human rabies - Texas, 2009. MMWR Morb Mortal Wkly Rep. 2010;59:185-90.

59. Gilbert AT, Petersen BW, Recuenco S, et al. Evidence of rabies virus exposure among humans in the Peruvian Amazon. Am J Trop Med Hyg. 2012;87:206-15.

60. Bronnert J, Wilde H, Tepsumethanon V, Lumlertdacha B, Hemachudha T. Organ transplantations and rabies transmission. J Travel Med. 2007;14:177-80.

61. Centers for Disease Control. Human-to-human transmission of rabies via a corneal transplant - France. MMWR Morb Mortal Wkly Rep. 1980;29:25-6.

62. Centers for Disease Control. Human-to-human transmission of rabies via corneal transplant--Thailand. MMWR Morb Mortal Wkly Rep. 1981;30:473-4.

63. Centers for Disease Control and Prevention. Update: investigation of rabies infections in organ donor and transplant recipients-Alabama, Arkansas, Oklahoma, and Texas, 2004. MMWR Morb Mortal Wkly Rep. 2004;53:615-6.

64. Centers for Disease Control and Prevention. Investigation of rabies infections in organ donor and transplant recipients--Alabama, Arkansas, Oklahoma, and Texas, 2004. MMWR Morb Mortal Wkly Rep. 2004;53:586-9.

65. Gode GR, Bhide NK. Two rabies deaths after corneal grafts from one donor. Lancet. 1988;2:791.

66. Houff SA, Burton RC, Wilson RW, et al. Human-to-human transmission of rabies virus by corneal transplant. N Engl J Med. 1979;300:603-4.

67. Javadi MA, Fayaz A, Mirdehghan SA, Ainollahi B. Transmission of rabies by corneal graft. Cornea. 1996;15:431-3.

68. Manning SE, Rupprecht CE, Fishbein D, et al. Human rabies prevention--United States, 2008: recommendations of the Advisory Committee on Immunization Practices. MMWR Recomm Rep. 2008;57:1-28

69. Srinivasan A, Burton EC, Kuehnert MJ, et al. Transmission of rabies virus from an organ donor to four transplant recipients. $\mathrm{N}$ Engl J Med. 2005;352:1103-11.

70. Sureau P, Portnoi D, Rollin P, Lapresle C, Chaouni-Barbich A. Prevention of inter-human rabies transmission after corneal graft. C R Seances Acad Sci III. 1981;293:4.

71. Hellenbrand W, Meyer C, Rasch G, Steffens I, Ammon A. Cases of rabies in Germany following organ transplantation. Euro Surveill. 2005;10:E050224 6.

72. Maier T, Schwarting A, Mauer D, et al. Management and outcomes after multiple corneal and solid organ transplantations from a donor infected with rabies virus. Clin Infect Dis. 2010;50:1112-9.

73. Vetter JM, Frisch L, Drosten C, et al. Survival after transplantation of corneas from a rabies-infected donor. Cornea. 2011;30:241-4.

74. Wallace RM, Stanek D, Griese S, et al. A large-scale, rapid public health response to rabies in an organ recipient and the previously undiagnosed organ donor. Zoonoses Public Health. 2014;61:560-70 
75. Vora NM, Basavaraju SV, Feldman KA, et al. Raccoon rabies virus variant transmission through solid organ transplantation. JAMA. 2013;310:398-407.

76. Centers for Disease Control and Prevention. Recovery of a patient from clinical rabies--California, 2011. MMWR Morb Mortal Wkly Rep. 2012;61:61-5.

77. Willoughby RE Jr, Tieves KS, Hoffman GM, et al. Survival after treatment of rabies with induction of coma. N Engl J Med. 2005;352:2508-14.

78. Aramburo A, Willoughby RE, Bollen AW, et al. Failure of the Milwaukee protocol in a child with rabies. Clin Infect. 2011;53:572-4.

79. Rabies registry home page. At http://www.chw.org/display/PPF/ DocID/33223/router.asp.

80. Cramer CH 2nd, Shieck V, Thomas SE, Kershaw DB, Magee JC, Lopez MJ. Immune response to rabies vaccination in pediatric transplant patients. Pediatr Transplant. 2008;12:874-7.

81. Rodriguez-Romo R, Morales-Buenrostro LE, Lecuona L, et al. Immune response after rabies vaccine in a kidney transplant recipient. Transpl Infect Dis. 2011;13:492-5.

82. Vora NM, Orciari LA, Niezgoda M, et al. Clinical management and humoral immune responses to rabies post-exposure prophylaxis among three patients who received solid organs from a donor with rabies. Transpl Infect Dis. 2015;17:389-95.

83. Buchmeier MJ, de la Torres J, Peters CJ. Arenaviridae: the viruses and their replication. In: Knipe DM, Howley PM, editors. Field's virology. 5th ed. Philadelphia: Lippincott Williams \& Wilkins. p. 2007.

84. Gregg MB. Recent outbreaks of lymphocytic choriomeningitis in the United States of America. Bull World Health Organ. 1975;52:549-53.

85. Hadler JL, Nelson R, Mshar P, Sosa LE. Survey of lymphocytic choriomeningitis virus diagnosis and testing - Connecticut, 2005. MMWR Morb Mortal Wkly Rep. 2006;55:398-9.

86. Barry A, Gunn J, Tormey P, et al. Lymphocytic choriomeningitis virus transmitted through solid organ transplantation - Massachusetts, 2008. MMWR Morb Mortal Wkly Rep. 2008;57:799-801.

87. MacNeil A, Stroher U, Farnon E, et al. Solid organ transplantassociated lymphocytic choriomeningitis, United States, 2011. Emerg Infect Dis. 2012;18:1256-62.

88. Schafer IJ, Miller R, Stroher U, Knust B, Nichol ST, Rollin PE. Notes from the field: a cluster of lymphocytic choriomeningitis virus infections transmitted through organ transplantationIowa, 2013. Am J Transplant. 2014;14:1459.

89. Centers for Disease Control and Prevention. Lymphocytic choriomeningitis virus infection in organ transplant recipients Massachusetts, Rhode Island, 2005. MMWR Morb Mortal Wkly Rep. 2005;54:537-9.

90. McCormick JB, King IJ, Webb PA, et al. Lassa fever. Effective therapy with ribavirin. N Engl J Med. 1986;314:20-6.

91. Peters CJ. Lymphocytic Choriomeningitis virus - an old enemy up to new tricks. N Engl J Med. 2006;354:2208-11.

92. Centers for Disease Control and Prevention. Update: interim guidance for minimizing risk for human lymphocytic choriomeningitis virus infection associated with pet rodents. MMWR Morb Mortal Wkly Rep. 2005;54:799-801.

93. Amman BR, Pavlin BI, Albarino CG, et al. Pet rodents and fatal lymphocytic choriomeningitis in transplant patients. Emerg Infect Dis. 2007;13:719-25.

94. Lou S, Xu B, Huang Q, et al. Molecular characterization of the newly identified human parvovirus 4 in the family Parvoviridae. Virology. 2012;422:59-69.

95. Allander T, Jartti T, Gupta S, et al. Human bocavirus and acute wheezing in children. Clin Infect Dis. 2007;44:904-10.

96. Arnold JC, Singh KK, Spector SA, Sawyer MH. Human bocavirus: prevalence and clinical spectrum at a children's hospital. Clin Infect Dis. 2006;43:283-8.
97. Fry AM, Lu X, Chittaganpitch M, et al. Human bocavirus: a novel parvovirus epidemiologically associated with pneumonia requiring hospitalization in Thailand. J Infect Dis. 2007;195:1038-45.

98. Garbino J, Soccal PM, Aubert JD, et al. Respiratory viruses in bronchoalveolar lavage: a hospital-based cohort study in adults. Thorax. 2009;64:399-404.

99. Kesebir D, Vazquez M, Weibel C, et al. Human bocavirus infection in young children in the United States: molecular epidemiological profile and clinical characteristics of a newly emerging respiratory virus. J Infect Dis. 2006;194:1276-82.

100. Longtin J, Bastien M, Gilca R, et al. Human bocavirus infections in hospitalized children and adults. Emerg Infect Dis. 2008;14:217-21.

101. Manning A, Russell V, Eastick K, et al. Epidemiological profile and clinical associations of human bocavirus and other human parvoviruses. J Infect Dis. 2006;194:1283-90.

102. Tozer SJ, Lambert SB, Whiley DM, et al. Detection of human bocavirus in respiratory, fecal, and blood samples by real-time PCR. J Med Virol. 2009;81:488-93.

103. Principi N, Piralla A, Zampiero A, et al. Bocavirus infection in otherwise healthy children with respiratory disease. PLoS One. 2015; 10:e0135640.

104. Schenk T, Strahm B, Kontny U, Hufnagel M, Neumann-Haefelin D, Falcone V. Disseminated bocavirus infection after stem cell transplant. Emerg Infect Dis. 2007;13:1425-7.

105. Schenk T, Maier B, Hufnagel M, et al. Persistence of human bocavirus DNA in immunocompromised children. Pediatr Infect Dis J. 2011;30:82-4.

106. de Vries JJ, Bredius RG, van Rheenen PF, et al. Human bocavirus in an immunocompromised child presenting with severe diarrhea. J Clin Microbiol. 2009;47:1241-3.

107. Costa C, Bergallo M, Cavallo R. Detection of human bocavirus in bronchoalveolar lavage from Italian adult patients. J Clin Virol. 2009;45:81-2.

108. Miyakis S, van Hal SJ, Barratt J, Stark D, Marriott D, Harkness $\mathrm{J}$. Absence of human bocavirus in bronchoalveolar lavage fluid of lung transplant patients. J Clin Virol. 2009;44:179-80.

109. Muller A, Klinkenberg D, Vehreschild J, et al. Low prevalence of human metapneumovirus and human bocavirus in adult immunocompromised high risk patients suspected to suffer from Pneumocystis pneumonia. J Infect. 2009;58:227-31.

110. Endo R, Ishiguro N, Kikuta H, et al. Seroepidemiology of human bocavirus in Hokkaido prefecture, Japan. J Clin Microbiol. 2007;45:3218-23.

111. The FilmArray® Respiratory Panels. 2012. At http://www.biofiredx. com/FilmArray/RespiratoryTest.html. Accessed 20 Sept 2012.

112. Biagini P, Dussol B, Touinssi M, et al. Human parvovirus 4 in kidney transplant patients, France. Emerg Infect Dis. 2008;14:1811-2.

113. Simmons R, Sharp C, McClure CP, et al. Parvovirus 4 infection and clinical outcome in high-risk populations. J Infect Dis. 2012;205:1816-20.

114. Benjamin LA, Lewthwaite P, Vasanthapuram R, et al. Human parvovirus 4 as potential cause of encephalitis in children, India. Emerg Infect Dis. 2011;17:1484-7.

115. Touinssi M, Reynaud-Gaubert M, Gomez C, et al. Parvovirus 4 in French in-patients: a study of hemodialysis and lung transplant cohorts. J Med Virol. 2011;83:717-20.

116. Schieble JH, Fox VL, Lennette EH. A probable new human picornavirus associated with respiratory diseases. Am J Epidemiol. 1967;85:297-310.

117. Midgley CM, Jackson MA, Selvarangan R, et al. Severe respiratory illness associated with enterovirus D68 - Missouri and Illinois, 2014. MMWR Morb Mortal Wkly Rep. 2014;63:798-9.

118. Midgley CM, Watson JT, Nix WA, et al. Severe respiratory illness associated with a nationwide outbreak of enterovirus D68 in the 
USA (2014): a descriptive epidemiological investigation. Lancet Respir Med. 2015;3:879-87.

119. Holm-Hansen CC, Midgley SE, Fischer TK. Global emergence of enterovirus D68: a systematic review. Lancet Infect Dis. 2016;16(5):e64-75.

120. Schuster JE, Miller JO, Selvarangan R, et al. Severe enterovirus 68 respiratory illness in children requiring intensive care management. J Clin Virol. 2015;70:77-82.

121. Greninger AL, Naccache SN, Messacar K, et al. A novel outbreak enterovirus D68 strain associated with acute flaccid myelitis cases in the USA (2012-14): a retrospective cohort study. Lancet Infect Dis. 2015;15:671-82.

122. Waghmare A, Pergam SA, Jerome KR, Englund JA, Boeckh M, Kuypers J. Clinical disease due to enterovirus D68 in adult hematologic malignancy patients and hematopoietic cell transplant recipients. Blood. 2015;125:1724-9.

123. Baas MC, van Donselaar KA, Florquin S, van Binnendijk RS, ten Berge IJ, Bemelman FJ. Mumps: not an innocent bystander in solid organ transplantation. Am J Transplant. 2009;9:2186-9.

124. Bakshi N, Lawson J, Hanson R, Ames C, Vinters HV. Fatal mumps meningoencephalitis in a child with severe combined immunodeficiency after bone marrow transplantation. J Child Neurol. 1996;11:159-62.

125. Dayan GH, Quinlisk MP, Parker AA, et al. Recent resurgence of mumps in the United States. N Engl J Med. 2008;358:1580-9.

126. Hatchette TF, Mahony JB, Chong S, LeBlanc JJ. Difficulty with mumps diagnosis: what is the contribution of mumps mimickers? J Clin Virol. 2009;46:381-3.

127. Agamanolis DP, Tan JS, Parker DL. Immunosuppressive measles encephalitis in a patient with a renal transplant. Arch Neurol. 1979;36:686-90.

128. Centers for Disease Control and Prevention. Increased transmission and outbreaks of measles--European Region, 2011. MMWR Morb Mortal Wkly Rep. 2011;60:1605-10.

129. Freeman AF, Jacobsohn DA, Shulman ST, et al. A new complication of stem cell transplantation: measles inclusion body encephalitis. Pediatrics. 2004;114:e657-60.

130. Kaplan LJ, Daum RS, Smaron M, McCarthy CA. Severe measles in immunocompromised patients. JAMA. 1992;267:1237-41.

131. Final 2011 reports of nationally notifiable infectious diseases. MMWR Morb Mortal Wkly Rep. 2012;61:624-37.

132. Ljungman P, Fridell E, Lonnqvist B, et al. Efficacy and safety of vaccination of marrow transplant recipients with a live attenuated measles, mumps, and rubella vaccine. J Infect Dis. 1989;159:610-5

133. Ljungman P, Aschan J, Barkholt L, et al. Measles immunity after allogeneic stem cell transplantation; influence of donor type, graft type, intensity of conditioning, and graft-versus host disease. Bone Marrow Transplant. 2004;34:589-93.

134. Spoulou V, Giannaki M, Vounatsou M, Bakoula C, Grafakos S. Long-term immunity to measles, mumps and rubella after MMR vaccination among children with bone marrow transplants. Bone Marrow Transplant. 2004;33:1187-90.

135. Kano H, Mizuta K, Sakakihara Y, et al. Efficacy and safety of immunization for pre- and post- liver transplant children. Transplantation. 2002;74:543-50.

136. Kalman S, Bakkaloglu SA, Ozkaya O, Buyan N, Soylemezoglu O. Measles: a rare communicable disease in a child with renal transplantation. Pediatr Transplant. 2002;6:432-4.

137. Lee DG, Yoo JH, Choi JH, et al. A fatal case of measles pneumonia complicating an adult recipient of hemopoietic stem cell transplantation during the nationwide epidemic in Korea. Int $\mathbf{J}$ Infect Dis. 2006;10:410-1.

138. Machado CM, Goncalves FB, Pannuti CS, Dulley FL, de Souza VA. Measles in bone marrow transplant recipients during an outbreak in Sao Paulo, Brazil. Blood. 2002;99:83-7.
139. Mustafa MM, Weitman SD, Winick NJ, Bellini WJ, Timmons CF, Siegel JD. Subacute measles encephalitis in the young immunocompromised host: report of two cases diagnosed by polymerase chain reaction and treated with ribavirin and review of the literature. Clin Infect Dis. 1993;16:654-60.

140. Sternfeld T, Spori-Byrtus V, Riediger C, et al. Acute measles infection triggering an episode of liver transplant rejection. Int J Infect Dis. 2010;14:e528-30.

141. Turner A, Jeyaratnam D, Haworth F, et al. Measles-associated encephalopathy in children with renal transplants. Am J Transplant. 2006;6:1459-65.

142. Liu Y, Sun LY, Zhu ZJ, Lin W, Qu W, Zeng ZG. Measles virus infection in pediatric liver transplantation recipients. Transplant Proc. 2015;47:2715-8.

143. Klapper PE, Cleator GM, Clarke MC, Postlethwaite RJ. Measles immunisation. Arch Dis Child. 1991;66:369.

144. Bitnun A, Shannon P, Durward A, et al. Measles inclusion-body encephalitis caused by the vaccine strain of measles virus. Clin Infect Dis. 1999;29:855-61.

145. Storek J. Measles in bone marrow transplant recipients. Blood. 2002;99:3070

146. Aiello FB, Calabrese F, Furian L, et al. Mumps-associated nephritis mimicking acute rejection in a patient under chronic dialysis treatment because of graft dysfunction. Transpl Int. 2002;15:523-4.

147. Park SB, Jin KB, Hwang EA, et al. Case of adult mumps infection after renal transplantation. Transplant Proc. 2008;40:2442-3.

148. Eyre TA, Pelosi E, McQuaid S, et al. Mumps virus encephalomyelitis in a 19-year old male patient with an undefined severe combined immunodeficiency post-haematopoietic bone marrow transplantation: a rare fatal complication. J Clin Virol. 2013;57:165-8.

149. Lam HY, Yeap SK, Rasoli M, et al. Safety and clinical usage of Newcastle disease virus in cancer therapy. J Biomed Biotechnol. 2011;2011:718710.

150. Goebel SJ, Taylor J, Barr BC, et al. Isolation of avian paramyxovirus 1 from a patient with a lethal case of pneumonia. J Virol. 2007;81:12709-14.

151. Woolhouse ME, Howey R, Gaunt E, Reilly L, Chase-Topping M, Savill N. Temporal trends in the discovery of human viruses. Proc Biol Sci. 2008;275:2111-5.

152. Tyler KL. Emerging viral infections of the central nervous system: part 2. Arch Neurol. 2009;66:1065-74.

153. Marsh GA, de Jong C, Barr JA, et al. Cedar virus: a novel Henipavirus isolated from Australian bats. PLoS Pathog. 2012;8:e1002836.

154. Eaton BT, Broder CC, Middleton D, Wang LF. Hendra and Nipah viruses: different and dangerous. Nat Rev Microbiol. 2006;4:23-35.

155. Chua KB, Lam SK, Goh KJ, et al. The presence of Nipah virus in respiratory secretions and urine of patients during an outbreak of Nipah virus encephalitis in Malaysia. J Infect. 2001;42:40-3.

156. Gurley ES, Montgomery JM, Hossain MJ, et al. Person-to-person transmission of Nipah virus in a Bangladeshi community. Emerg Infect Dis. 2007;13:1031-7.

157. Goh KJ, Tan CT, Chew NK, et al. Clinical features of Nipah virus encephalitis among pig farmers in Malaysia. $\mathrm{N}$ Engl $\mathrm{J}$ Med. 2000;342:1229-35.

158. Hossain MJ, Gurley ES, Montgomery JM, et al. Clinical presentation of nipah virus infection in Bangladesh. Clin Infect Dis. 2008;46:977-84.

159. Tan CT, Goh KJ, Wong KT, et al. Relapsed and late-onset Nipah encephalitis. Ann Neurol. 2002;51:703-8.

160. Tan ST, Blake GB, Chambers S. Recurrent orf in an immunocompromised host. Br J Plast Surg. 1991;44:465-7. 
161. Geerninck K, Lukito G, Snoeck R, et al. A case of human orf in an immunocompromised patient treated successfully with cidofovir cream. J Med Virol. 2001;64:543-9.

162. Savage J, Black MM. Giant orf of finger in a patient with lymphoma. Proc R Soc Med. 1972;65:766.

163. Degraeve C, De Coninck A, Senneseael J, Rosseeuw D. Recurrent contagious ecthyma (orf) in an immunocompromised host successfully treated with cryotherapy. Dermatology. 1999;198:162-3.

164. Ara M, Zaballos P, Sanchez M, et al. Giant and recurrent orf virus infection in a renal transplant recipient treated with imiquimod. J Am Acad Dermatol. 2008;58:S39-40.

165. Rimoin AW, Mulembakani PM, Johnston SC, et al. Major increase in human monkeypox incidence 30 years after smallpox vaccination campaigns cease in the Democratic Republic of Congo. Proc Natl Acad Sci U S A. 2010;107:16262-7.

166. Reynolds MG, Damon IK. Outbreaks of human monkeypox after cessation of smallpox vaccination. Trends Microbiol. 2012;20:80-7.

167. Hutin YJ, Williams RJ, Malfait P, et al. Outbreak of human monkeypox, Democratic Republic of Congo, 1996 to 1997. Emerg Infect Dis. 2001;7:434-8.

168. Huhn GD, Bauer AM, Yorita K, et al. Clinical characteristics of human monkeypox, and risk factors for severe disease. Clin Infect Dis. 2005;41:1742-51.

169. Meyer H, Perrichot M, Stemmler M, et al. Outbreaks of disease suspected of being due to human monkeypox virus infection in the Democratic Republic of Congo in 2001. J Clin Microbiol. 2002;40:2919-21.

170. Lakis NS, Li Y, Abraham JL, et al. Novel poxvirus infection in an immune suppressed patient. Clin Infect Dis. 2015;61:1543-8.

171. 2012. At http://www.transplant-observatory.org/Pages/home. aspx. Accessed 13 Sept 2012.

172. Nikolay B, Diallo M, Boye CS, Sall AA. Usutu virus in Africa. Vector Borne Zoonotic Dis. 2011;11:1417-23.

173. WHO. Dengue: Guidelines for diagnosis, treatment, prevention and control. France: WHO Press; 2009.

174. Kliks SC, Nisalak A, Brandt WE, Wahl L, Burke DS. Antibodydependent enhancement of dengue virus growth in human monocytes as a risk factor for dengue hemorrhagic fever. Am J Trop Med Hyg. 1989;40:444.

175. Martina BEE, Koraka P, Osterhaus ADME. Dengue virus pathogenesis: an integrated view. Clin Microbiol Rev. 2009;22:564.

176. Rico-Hesse R. Dengue virus evolution and virulence models. Clin Infect Dis. 2007;44:1462.

177. Sierra B, Perez AB, Alvarez M, et al. Variation in inflammatory/regulatory cytokines in secondary, tertiary, and quaternary challenges with dengue virus. Am J Trop Med Hyg. 2012;87(3):538-47.

178. Azevedo LS, Carvalho DBM, Matuck T, et al. Dengue in renal transplant patients: a retrospective analysis. Transplantation. 2007;84:792-4.

179. Chacko B, John GT, Jacob C. Dengue shock syndrome in a renal transplant recipient. Transplantation. 2004;77:634-5.

180. Garcia JHP, Rocha TDS, Viana CFG, et al. Dengue shock syndrome in a liver transplant recipient. Tranplantation. 2006;82:850-1.

181. Park SB, Ryu SY, Jin KB, et al. Acute colitis associated with dengue fever in a renal transplant recipient. Transplant Proc. 2008;40:2431-2.

182. Renaud CJ, Manjit K, Pary S. Dengue has a benign presentation in renal transplant patients: a case series. Nephrology. 2007; 12:305-7.

183. Rigau-Perez JG, Vorndam V, Clark GG. The dengue and dengue hemorrhagic fever epidemic in Puerto Rico, 1994-1995. Am J Trop Med Hyg. 2001;64:67-74.

184. Tan FL, Loh DLSK, Prabhakaran K. Dengue haemorrhagic fever after living donor renal transplantation. Nephrol Dial Transplant. 2005;20:447-8.
185. Tangnararatchakit K, Tirapanich W, Tapaneya-Olarn W, et al. Severe nonfebrile dengue infection in an adolescent after postoperative kidney transplantation: a case report. Transplant Proc. 2012;44:303-6.

186. Prasad N, Bhadauria D, Sharma RK, Gupta A, Kaul A, Srivastava A. Dengue virus infection in renal allograft recipients: a case series during 2010 outbreak. Transpl Infect Dis. 2012;14:163-8.

187. Costa SD, da Silva GB Jr, Jacinto CN, et al. Dengue fever among renal transplant recipients: a series of 10 cases in a tropical country. Am J Trop Med Hyg. 2015;93:394-6.

188. Gupta RK, Gupta G, Chorasiya VK, et al. Dengue virus transmission from living donor to recipient in liver transplantation: a case report. J Clin Exp Hepatol. 2016;6:59-61.

189. Punzel M, Korukluoglu G, Caglayik DY, et al. Dengue virus transmission by blood stem cell donor after travel to Sri Lanka; Germany, 2013. Emerg Infect Dis. 2014;20:1366-9.

190. Kotton CN. Zika virus and solid organ transplantation: significant pathogen or harbinger of things to come? Transplantation. 2016;100:970-2.

191. Machado CM, Martins TC, Colturato I, et al. Epidemiology of neglected tropical diseases in transplant recipients. Review of the literature and experience of a Brazilian HSCT center. Rev Inst Med Trop Sao Paulo. 2009;51:309-24.

192. Azevedo LS, Lasmar EP, Contieri FLC, et al. Yellow fever vaccination in organ transplanted patients: is it safe? A multicenter study. Transpl Infect Dis. 2012;14:237-41.

193. Avelino-Silva VI, Leal FE, Sabino EC, et al. Yellow fever vaccine viremia following ablative BM suppression in AML. Bone Marrow Transplant. 2013;48:1008-9.

194. Charrel RN, de Lamballerie X, Raoult D. Chikungunya outbreaks--the globalization of vectorborne diseases. N Engl J Med. 2007;356:769-71.

195. Staples JE, Breiman RF, Powers AM. Chikungunya fever: an epidemiological review of a re-emerging infectious disease. Clin Infect Dis. 2009;49:942.

196. Bonilauri P, Bellini R, Calzolari M, et al. Chikungunya virus in Aedes albopictus, Italy. Emerg Infect Dis. 2008;14:852-4.

197. Borgherini G, Poubeau P, Jossaume A, et al. Persistent arthralgia associated with chikungunya virus: a study of 88 adult patients on Reunion island. Clin Infect Dis. 2008;47:469-75.

198. Simon F, Parola P, Grandadam M, et al. Chikungunya infection: an emerging rheumatism among travelers returned from Indian Ocean islands. Report of 47 cases. Medicine. 2007;86:123-37.

199. Borgherini G, Paubeau P, Staikowsky F, et al. Outbreak of chikungunya on Reunion island: early clinical and laboratory features in 157 adult patients. Clin Infect Dis. 2007;44:1401.

200. Chusri S, Siripaitoon P, Hirunpat S, Silpapojakul K. Case reports of neuro-chikungunya in southern Thailand. Am J Trop Med Hyg. 2011;85:386-9.

201. Kee AC, Yang S, Tambyah P. Atypical chikungunya virus infections in immunocompromised patients. Emerg Infect Dis. 2010;16:1038-40.

202. Dalla Gasperina D, Balsamo ML, Garavaglia SD, Rovida F, Baldanti F, Grossi PA. Chikungunya infection in a human immunodeficiency virus-infected kidney transplant recipient returning to Italy from the Dominican Republic. Transpl Infect Dis. 2015;17:876-9.

203. Couderc T, Gangneux N, Chretien F, et al. Chikungunya virus infection of corneal grafts. J Infect Dis. 2012;206:851-9.

204. Boshra H, Lorenzo G, Busquets N, Brun A. Rift valley fever: recent insights into pathogenesis and prevention. $\mathrm{J}$ Virol. 2011;85:6098-105.

205. Hassan OA, Ahlm C, Sang R, Evander M. The 2007 Rift Valley fever outbreak in Sudan. PLoS Negl Trop Dis. 2011;5:e1229. 
206. Zhang YZ, He YW, Dai YA, et al. Hemorrhagic fever caused by a novel bunyavirus in China: pathogenesis and correlates of fatal outcome. Clin Infect Dis. 2012;54:527-33.

207. Meier M, Helmchen U, Fricke L, Ulrich R, Schutt M. Acute hantavirus infection or renal transplant rejection. Transpl Infect Dis. 2007;9:225-8.

208. Moutschen P, Bourhaba M, Frippiat F, et al. A pauci-symptomatic case of documented hantavirus (Puumala) infection in a patient under anti-TNF treatment. J Clin Virol. 2011;50:247-8.

209. Sinisalo M, Vapalahti O, Ekblom-Kullberg S, et al. Headache and low platelets in a patient with acute leukemia. J Clin Virol. 2010;48:159-61.

210. Huggins JW, Hsiang CM, Cosgriff TM, et al. Prospective, doubleblind, concurrent, placebo-controlled clinical trial of intravenous ribavirin therapy of hemorrhagic fever with renal syndrome. J Infect Dis. 1991;164:1119-27.

211. Mertz GJ, Miedzinski L, Goade D, et al. Placebo-controlled, double-blind trial of intravenous ribavirin for the treatment of hantavirus cardiopulmonary syndrome in North America. Clin Infect Dis. 2004;39:1307-13.

212. Qian DY, Ding YS, Chen GF, et al. A placebo-controlled clinical trial of prednisone in the treatment of early hemorrhagic fever. J Infect Dis. 1990;162:1213-4.

213. Kortepeter MG, Bausch DG, Bray M. Basic clinical and laboratory features of filoviral hemorrhagic fever. J Infect Dis. 2011;204(Suppl 3):S810-6.

214. Leroy EM, Gonzalez JP, Baize S. Ebola and Marburg haemorrhagic fever viruses: major scientific advances, but a relatively minor public health threat for Africa. Clin Microbiol Infect. 2011;17:964-76.

215. 2014. Ebola outbreak in West Africa - outbreak distribution map, 2016. At http://www.cdc.gov/vhf/ebola/outbreaks/2014-westafrica/distribution-map.html. Accessed 28 May 2016.

216. Bausch DG, Towner JS, Dowell SF, et al. Assessment of the risk of Ebola virus transmission from bodily fluids and fomites. J Infect Dis. 2007;196(Suppl 2):S142-7.
217. Kaul DR, Mehta AK, Wolfe CR, Blumberg E, Green M. Ebola virus disease: implications for solid organ transplantation. Am J Transplant. 2015;15:5-6.

218. Mueller NJ, Takeuchi Y, Mattiuzzo G, Scobie L. Microbial safety in xenotransplantation. Curr Opin Organ Transplant. 2011;16:201-6.

219. Scobie L, Takeuchi Y. Porcine endogenous retrovirus and other viruses in xenotransplantation. Curr Opin Organ Transplant. 2009;14:175-9.

220. Patience C, Takeuchi Y, Weiss RA. Infection of human cells by an endogenous retrovirus of pigs. Nat Med. 1997;3:282-6.

221. Hermida-Prieto M, Domenech N, Moscoso I, et al. Lack of crossspecies transmission of porcine endogenous retrovirus (PERV) to transplant recipients and abattoir workers in contact with pigs. Transplantation. 2007;84:548-50.

222. Gu C, Wei X, Wang Y, et al. No infection with porcine endogenous retrovirus in recipients of acellular porcine aortic valves: a twoyear study. Xenotransplantation. 2008;15:121-8.

223. Issa NC, Wilkinson RA, Griesemer A, et al. Absence of replication of porcine endogenous retrovirus and porcine lymphotropic herpesvirus type 1 with prolonged pig cell microchimerism after pig-to-baboon xenotransplantation. J Virol. 2008;82:12441-8.

224. Valdes-Gonzalez R, Dorantes LM, Bracho-Blanchet E, RodriguezVentura A, White DJ. No evidence of porcine endogenous retrovirus in patients with type 1 diabetes after long-term porcine islet xenotransplantation. J Med Virol. 2010;82:331-4.

225. Garkavenko O, Croxson MC, Irgang M, Karlas A, Denner J, Elliott RB. Monitoring for presence of potentially xenotic viruses in recipients of pig islet xenotransplantation. J Clin Microbiol. 2004;42:5353-6.

226. Garkavenko O, Dieckhoff B, Wynyard S, et al. Absence of transmission of potentially xenotic viruses in a prospective pig to primate islet xenotransplantation study. J Med Virol. 2008;80:2046-52.

227. Network USOPaT. Policy 4: identification of transmissible diseases in organ recipients. 2010:4. 